SUPPORTING INFORMATION

\title{
Synthesis of Ni(II) Complexes Supported by Tetradentate Mixed Donor Bis(amido)/Phosphine/Phosphido Ligands by Phosphine Substituent Elimination
}

\author{
Kyounghoon Lee, Curtis E. Moore, Christine M. Thomas*
}

The Ohio State University, Department of Chemistry and Biochemistry, 100 West $18^{\text {th }}$ Avenue, Columbus, Ohio 43210, United States

Corresponding Author Email: thomas.3877@osu.edu

Table of Contents

\begin{tabular}{|c|c|}
\hline Experimental Section & S3-S7 \\
\hline $\begin{array}{l}\text { Table S1. Crystallographic data for }{ }^{4 \mathrm{Ph}}[\mathrm{PNNP}] \mathrm{Ni}(\mathbf{1}),\left\{\mathrm{K}(\mathrm{THF})_{4}\right\}^{3 \mathrm{Ph}}[\mathrm{PNNP}] \mathrm{Ni}(\mathbf{2}) \text {, } \\
\text { and }\left\{\mathrm{Li}(\mathrm{THF})_{2}\right\}_{2}{ }^{2 \mathrm{Ph}}[\mathrm{PNNP}] \mathrm{Ni}(\mathbf{4}) \text {. }\end{array}$ & S8 \\
\hline Figure S1. ${ }^{1} \mathrm{H}$ NMR spectrum for ${ }^{4 \mathrm{Ph}}[\mathrm{PNNP}] \mathrm{Ni}(\mathbf{1})$ & S9 \\
\hline Figure S2. ${ }^{13} \mathrm{C}\left\{{ }^{1} \mathrm{H}\right\}$ NMR spectrum for ${ }^{4 \mathrm{Ph}}[\mathrm{PNNP}] \mathrm{Ni}(\mathbf{1})$. & S10 \\
\hline Figure S3. ${ }^{31} \mathrm{P}\left\{{ }^{1} \mathrm{H}\right\}$ NMR spectrum for ${ }^{4 \mathrm{Ph}}[\mathrm{PNNP}] \mathrm{Ni}(\mathbf{1})$. & S11 \\
\hline Figure S4. ${ }^{1} \mathrm{H}$ NMR spectrum for $\left\{\mathrm{K}(\mathrm{THF})_{\mathrm{x}}\right\}^{3 \mathrm{Ph}}[\mathrm{PNNP}] \mathrm{Ni}(\mathbf{2})$. & S12 \\
\hline Figure S5. ${ }^{13} \mathrm{C}\left\{{ }^{1} \mathrm{H}\right\}$ NMR spectrum for $\{\mathrm{K}(\mathrm{THF}) \mathrm{x}\}{ }^{3 \mathrm{Ph}}[\mathrm{PNNP}] \mathrm{Ni}(\mathbf{2})$. & S13 \\
\hline Figure S6. ${ }^{31} \mathrm{P}\left\{{ }^{1} \mathrm{H}\right\}$ NMR spectrum for $\left.\left\{\mathrm{K}(\mathrm{THF})_{x}\right\}\right]^{3 \mathrm{Ph}}[\mathrm{PNNP}] \mathrm{Ni}(\mathbf{2})$. & S14 \\
\hline Figure S7. ${ }^{1} \mathrm{H}$ NMR spectrum for $\left\{\mathrm{K}(\mathrm{THF})_{\mathrm{x}}\right\}_{2}{ }^{2 \mathrm{Ph}}[\mathrm{PNNP}] \mathrm{Ni}(\mathbf{3})$ & S15 \\
\hline Figure S8. ${ }^{13} \mathrm{C}\left\{{ }^{1} \mathrm{H}\right\}$ NMR spectrum for $\left\{\mathrm{K}(\mathrm{THF})_{\mathrm{x}}\right\}_{2}{ }^{2 \mathrm{Ph}}[\mathrm{PNNP}] \mathrm{Ni}(\mathbf{3})$. & S16 \\
\hline Figure S9. ${ }^{31} \mathrm{P}\left\{{ }^{1} \mathrm{H}\right\}$ NMR spectrum for $\left\{\mathrm{K}(\mathrm{THF})_{\mathrm{x}}\right\}_{2}{ }^{2 \mathrm{Ph}}[\mathrm{PNNP}] \mathrm{Ni}(\mathbf{3})$. & S17 \\
\hline Figure S10. ${ }^{1} \mathrm{H}$ NMR spectrum for $\left\{\mathrm{Li}(\mathrm{THF})_{2}\right\}_{2}{ }^{2 \mathrm{Ph}}[\mathrm{PNNP}] \mathrm{Ni}(\mathbf{4})$. & S18 \\
\hline Figure S11. ${ }^{13} \mathrm{C}\left\{{ }^{1} \mathrm{H}\right\}$ NMR spectrum for $\left\{\mathrm{Li}(\mathrm{THF})_{2}\right\}_{2}{ }^{2 \mathrm{Ph}}[\mathrm{PNNP}] \mathrm{Ni}(\mathbf{4})$. & S19 \\
\hline Figure S12. ${ }^{31} \mathrm{P}\left\{{ }^{1} \mathrm{H}\right\}$ NMR spectrum for $\left\{\mathrm{Li}(\mathrm{THF})_{2}\right\}_{2}{ }^{2 \mathrm{Ph}}[\mathrm{PNNP}] \mathrm{Ni}(\mathbf{4})$. & S20 \\
\hline $\begin{array}{l}\text { Figure S13. }{ }^{1} \mathrm{H} \text { NMR spectrum of the reaction of } \mathrm{Ni}(\mathrm{COD})_{2}, \mathrm{H}_{2}{ }^{4 \mathrm{Ph}}[\mathrm{PNNP}] \text {, and } 3 \mathrm{KH} \\
\text { carried out in THF, after volatiles were removed under vacuum. }\end{array}$ & S21 \\
\hline $\begin{array}{l}\text { Figure S14. }{ }^{31} \mathrm{P}\left\{{ }^{\mathrm{l}} \mathrm{H}\right\} \mathrm{NMR} \text { spectrum of the reaction of } \mathrm{Ni}(\mathrm{COD})_{2}, \mathrm{H}_{2}{ }^{4 \mathrm{Ph}}[\mathrm{PNNP}] \text {, and } \\
3 \mathrm{KH} \text { carried out in THF, after volatiles were removed under vacuum. }\end{array}$ & S22 \\
\hline
\end{tabular}




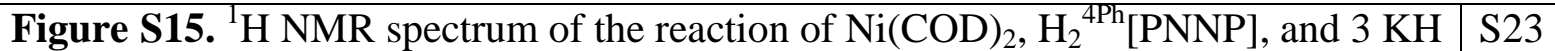
carried out in THF-d 8 .

Figure S16. ${ }^{3 \mathrm{P}} \mathrm{P}\left\{{ }^{1} \mathrm{H}\right\}$ NMR spectrum for the reaction of $\mathrm{Ni}(\mathrm{COD})_{2}, \mathrm{H}_{2}{ }^{4 \mathrm{Ph}}[\mathrm{PNNP}], \quad \mathrm{S} 24$ and $3 \mathrm{KH}$ carried out in THF-d $\mathrm{d}_{8}$.

Figure S17. ${ }^{1} \mathrm{H}$ NMR spectrum of the reaction of $\mathrm{Ni}(\mathrm{COD})_{2}, \mathrm{H}_{2}{ }^{4 \mathrm{Ph}}[\mathrm{PNNP}]$, and 3 S25

${ }^{n} \mathrm{BuLi}$ carried out in THF, evaporated to dryness under vacuum, and resuspended in $\mathrm{C}_{6} \mathrm{D}_{6}$.

Figure S18. ${ }^{31} \mathrm{P}\left\{{ }^{1} \mathrm{H}\right\}$ NMR spectrum for the reaction of $\mathrm{Ni}(\mathrm{COD})_{2}, \mathrm{H}_{2}{ }^{4 \mathrm{Ph}}[\mathrm{PNNP}], \quad \mathrm{S} 26$ and $3{ }^{n} \mathrm{BuLi}$ carried out in THF, evaporated to dryness under vacuum, and resuspended in $\mathrm{C}_{6} \mathrm{D}_{6}$.

Figure S19. ${ }^{31} \mathrm{P}\left\{{ }^{1} \mathrm{H}\right\}$ NMR spectrum for the reaction of $\left\{\mathrm{K}(\mathrm{THF})_{\mathrm{x}}\right\}_{2}{ }^{2 \mathrm{Ph}}[\mathrm{PNNP}] \mathrm{Ni}(3)$ and 2 equiv 18-crown-6 in THF.

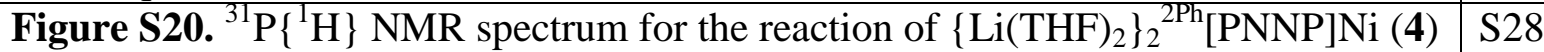
and 4 equiv 12-crown-4 in THF.

Figure S21. GC-MS chromatogram and mass spectrum for the reaction of $\mathrm{Ni}(\mathrm{COD})_{2}$, $\mathrm{H}_{2}{ }^{4 \mathrm{Ph}}[\mathrm{PNNP}]$, and $3 \mathrm{KH}$ carried out in THF, evaporated to dryness under vacuum, and resuspended in hexane.

Figure S22. GC-MS chromatogram and mass spectrum for the reaction of $\mathrm{Ni}(\mathrm{COD})_{2}, \quad \mathrm{~S} 30$ $\mathrm{H}_{2}{ }^{4 \mathrm{Ph}}[\mathrm{PNNP}]$, and $3^{n} \mathrm{BuLi}$ carried out in THF, evaporated to dryness under vacuum, and resuspended in hexane. 


\section{Experimental Section.}

General Considerations. All manipulations were carried out under an inert atmosphere using a nitrogen-filled glovebox or standard Schlenk techniques unless otherwise noted. All glassware was oven-dried prior to use. All solvents were degassed by sparging with ultra-high purity argon and dried via passage through columns of drying agents using a Seca solvent purification system from Pure Process Technologies. $\mathrm{C}_{6} \mathrm{D}_{6}, \mathrm{CD}_{3} \mathrm{CN}$, and $\mathrm{CDCl}_{3}$ were dried over $\mathrm{CaH}_{2}$, distilled, degassed by repeated freeze-pump-thaw cycles, and stored over pre-activated 3 $\AA$ molecular sieves. THF- $d_{8}$ was dried over Na/benzophenone, distilled, degassed by freezepump-thaw cycles, and stored over pre-activated $3 \AA$ molecular sieves. $\mathrm{H}_{2}{ }^{4 \mathrm{Ph}}[\mathrm{PNNP}]$ was prepared following the reported procedure. ${ }^{1}$ Pure potassium hydride $(\mathrm{KH})$ was prepared by washing commercial $30 \mathrm{wt} \% \mathrm{KH}$ dispersed in mineral oil with excess hexane, and stored in a nitrogen-filled glovebox. All other chemicals were purchased from commercial vendors and used without further purification.

Spectroscopic Characterization and Physical Measurements. ${ }^{1} \mathrm{H}$ and ${ }^{31} \mathrm{P}$ NMR data were recorded on a Bruker DPX-400 instrument operating at $400 \mathrm{MHz}$ for ${ }^{1} \mathrm{H}$ and $162.0 \mathrm{MHz}$ for ${ }^{31} \mathrm{P}$. ${ }^{13} \mathrm{C}$ NMR data were acquired on a Bruker AVANCE III instrument operating at $150.9 \mathrm{MHz}$. Chemical shifts are reported in $\delta$ units in ppm referenced to residual solvent peaks $\left({ }^{1} \mathrm{H}\right.$ and $\left.{ }^{13} \mathrm{C}\right)$ or to $85 \% \mathrm{H}_{3} \mathrm{PO}_{4}\left({ }^{31} \mathrm{P} ; \delta 0.0\right)$.

GC-MS data were collected on an Agilent 7890B/5977B GC/MSD with a split to both FID and mass spectrometer detectors using $\mathrm{He}$ as the carrier gas. Elemental microanalysis data (CHN) were collected by Midwest Microlab, Indianapolis, IN. High-resolution MS data were obtained using a Bruker Impact II instrument (Bruker Daltronics) with an electrospray ionization (ESI) source and quadrupole time-of-flight (Q-TOF) analyzer system. 
${ }^{4 \mathbf{P h}}[\mathbf{P N N P}] \mathbf{N i}(\mathbf{1})$. To a stirring suspension of $\mathrm{NiCl}_{2}(\mathrm{DME})(0.10 \mathrm{~g}, 0.46 \mathrm{mmol})$ in $\mathrm{THF}(5$ $\mathrm{mL})$ was added a solution of $\mathrm{H}_{2}{ }^{4 \mathrm{Ph}}[\mathrm{PNNP}](0.264 \mathrm{~g}, 0.455 \mathrm{mmol})$ in THF $(5 \mathrm{~mL})$. The resulting light blue precipitate was stirred overnight, filtered, and washed with THF (10 mL). The isolated solid was resuspended in THF $(10 \mathrm{~mL})$ and a solution of $\mathrm{NaO}^{t} \mathrm{Bu}(0.087 \mathrm{~g}, 0.91 \mathrm{mmol})$ in $\mathrm{THF}$ $(5 \mathrm{~mL})$ was added. The dark brown mixture was stirred for $2 \mathrm{~h}$. Deionized (DI) water (50 mL) was added into the reaction mixture in air, forming a brown precipitate. The precipitate was filtered, washed with DI water $(50 \mathrm{~mL})$ in air, and dried under vacuum overnight. Dark brown blocks were obtained by the vapor diffusion of $\mathrm{Et}_{2} \mathrm{O}$ into a solution of $\mathbf{1}$ in $\mathrm{CH}_{2} \mathrm{Cl}_{2}$. Yield: 0.203 g (71 \%). Anal. Calcd for $\mathrm{C}_{38} \mathrm{H}_{32} \mathrm{~N}_{2} \mathrm{NiP}_{2} \cdot\left(\mathrm{CH}_{2} \mathrm{Cl}_{2}\right)_{0.5}$ : C, 68.02; H, 4.89; N, 4.12. Found: C, 67.59; H, 4.93; N, 4.49 (Note: Although no solvent molecules were found in the crystal lattice of 1, the ${ }^{1} \mathrm{H}$ NMR spectrum of bulk dried samples of $\mathbf{1}$ consistently contained $\mathrm{CH}_{2} \mathrm{Cl}_{2}$ with a relative integration of $\sim 0.75$ equiv of $\mathrm{CH}_{2} \mathrm{Cl}_{2}$ per molecule of $\left.\mathbf{1}\right) .{ }^{1} \mathrm{H}$ NMR $\left(\mathrm{CDCl}_{3}, 400 \mathrm{MHz}\right): \delta$ 7.36 (m, Ar-H, 8H), 7.25 (m, Ar-H, 4H), 7.13 - 7.03 (m, Ar-H, 10H), 6.77 (m, Ar-H, 2H), 6.44 (m, Ar-H, 2H), $6.21(\mathrm{t}, \mathrm{Ar}-\mathrm{H}, 2 \mathrm{H}), 3.56\left(\mathrm{~s}, \mathrm{NCH}_{2}, 4 \mathrm{H}\right) .{ }^{13} \mathrm{C}\left\{{ }^{1} \mathrm{H}\right\} \mathrm{NMR}\left(\mathrm{CDCl}_{3}, 150.9 \mathrm{MHz}\right): \delta$ $165.6(\mathrm{~s}), 133.4(\mathrm{~s}), 133.1$ (s), 132.7 (s), $130.8(\mathrm{vt}), 130.2$ (s), $128.4(\mathrm{~s}), 118.9$ (s), 112.7 (s), 109.5 (s), 54.3 (s). ${ }^{31} \mathrm{P}\left\{{ }^{1} \mathrm{H}\right\} \mathrm{NMR}\left(\mathrm{CDCl}_{3}, 162.0 \mathrm{MHz}\right): \delta 39.7$ (s). ESI-MS m/z: calcd for $\mathrm{C}_{38} \mathrm{H}_{33} \mathrm{~N}_{2} \mathrm{NiP}_{2}$ 637.1472; found 637.1469.

$\left\{\mathbf{K}(\mathbf{T H F})_{\mathbf{x}}\right\}^{3 \mathrm{Ph}}[\mathbf{P N N P}] \mathbf{N i}(\mathbf{2})$. To a stirring suspension of KH (9.5 mg, $\left.0.24 \mathrm{mmol}\right)$ in THF (5 $\mathrm{mL})$ was added a solution of $\mathrm{H}_{2}{ }^{4 \mathrm{Ph}}[\mathrm{PNNP}](0.106 \mathrm{~g}, 0.183 \mathrm{mmol})$ in THF $(5 \mathrm{~mL})$. The reaction mixture was stirred for $2 \mathrm{~h}$. To the resulting orange-yellow solution was added a solution of $\mathrm{Ni}(\mathrm{COD})_{2}(0.050 \mathrm{~g}, 0.18 \mathrm{mmol})$ in THF $(5 \mathrm{~mL})$. The resulting dark red solution was stirred overnight. The solution was evaporated to dryness under vacuum, resuspended in THF (3 mL), and filtered through a pad of Celite. The solution was layered with pentane and stored at $-30{ }^{\circ} \mathrm{C}$, 
which resulted in the formation of dark red blocks. Yield: $0.115 \mathrm{~g}(89 \%)$. Anal. Calcd for $\mathrm{C}_{32} \mathrm{H}_{27} \mathrm{KN}_{2} \mathrm{NiP}_{2}$. (THF) $)_{1.5}:$ C, 64.51; H, 5.56; N, 3.96. Found: C, 63.76; H, 5.58; N, 3.80 (Note: Although four potassium-bound THF molecules per molecule of $\mathbf{2}$ were found in the crystal structure, ${ }^{1} \mathrm{H}$ NMR spectra of dried bulk samples of 2 only contained 1.5 molecules of THF based on integration). ${ }^{1} \mathrm{H}$ NMR $\left(\mathrm{CD}_{3} \mathrm{CN}, 400 \mathrm{MHz}\right)$ : $\delta 7.45$ (br, Ar-H, 3H), $7.32(\mathrm{~m}, \mathrm{Ar}-\mathrm{H}, 3 \mathrm{H})$, 7.24 (br, Ar-H, 4H), 7.02 (m, Ar-H, 2H), $6.92-6.84$ (m, Ar-H, 2H), $6.83-6.70$ (m, Ar-H, 4H), $6.65(\mathrm{~m}, \mathrm{Ar}-\mathrm{H}, 1 \mathrm{H}), 6.17-6.03(\mathrm{~m}, \mathrm{Ar}-\mathrm{H}, 3 \mathrm{H}), 5.91(\mathrm{~m}, \mathrm{Ar}-\mathrm{H}, 1 \mathrm{H}), 3.44\left(\mathrm{~m}, \mathrm{NCH}_{2}, 2 \mathrm{H}\right), 3.29(\mathrm{t}$, $\left.\mathrm{NCH}_{2}, 2 \mathrm{H}\right) .{ }^{13} \mathrm{C}\left\{{ }^{1} \mathrm{H}\right\} \mathrm{NMR}\left(\mathrm{CD}_{3} \mathrm{CN}, 150.9 \mathrm{MHz}\right): \delta 165.0(\mathrm{~d}, J=24 \mathrm{~Hz}), 164.3(\mathrm{~d}, J=12 \mathrm{~Hz})$, $150.1(\mathrm{~d}, J=39 \mathrm{~Hz}), 136.0(\mathrm{~d}, J=11 \mathrm{~Hz}), 135.8(\mathrm{~d}, J=11 \mathrm{~Hz}), 135.5(\mathrm{~s}), 135.2(\mathrm{~s}), 134.2(\mathrm{~s})$, 134.0 (s), 133.9 (s), 133.5 (d, $J=11 \mathrm{~Hz}), 133.1$ (s), 132.9 (s), 132.8 (d, $J=10 \mathrm{~Hz}), 129.9$ (s), $129.6(\mathrm{~d}, J=11 \mathrm{~Hz}), 128.8(\mathrm{~d}, J=10 \mathrm{~Hz}), 127.9(\mathrm{~d}, J=6 \mathrm{~Hz}), 127.1(\mathrm{~s}), 125.0(\mathrm{~s}), 122.1(\mathrm{~d}, J=$ $4 \mathrm{~Hz}), 121.8(\mathrm{~d}, J=5 \mathrm{~Hz}), 110.7(\mathrm{~d}, J=4 \mathrm{~Hz}), 109.3(\mathrm{~d}, J=7 \mathrm{~Hz}), 108.9(\mathrm{~d}, \mathrm{~J}=11 \mathrm{~Hz}), 107.4$ (s), $55.2(\mathrm{~s}), 53.2(\mathrm{~d}, J=4 \mathrm{~Hz}) .{ }^{31} \mathrm{P}\left\{{ }^{1} \mathrm{H}\right\} \operatorname{NMR}\left(\mathrm{CD}_{3} \mathrm{CN}, 162.0 \mathrm{MHz}\right): \delta 37.5(\mathrm{~d}, J=6 \mathrm{~Hz}), 35.3$ $(\mathrm{d}, J=6 \mathrm{~Hz})$.

$\left\{\mathbf{K}(\mathbf{T H F})_{\mathbf{x}}\right\}_{2}{ }^{2 \mathrm{Ph}}[\mathbf{P N N P}] \mathbf{N i}(\mathbf{3})$. To a stirring suspension of KH $(0.022 \mathrm{~g}, 0.55 \mathrm{mmol})$ in THF (5 mL) was added a solution of $\mathrm{H}_{2}{ }^{4 \mathrm{Ph}}[\mathrm{PNNP}](0.106 \mathrm{~g}, 0.183 \mathrm{mmol})$ in $\mathrm{THF}(5 \mathrm{~mL})$. The reaction mixture was stirred for $1 \mathrm{~h}$. To the resulting orange-yellow solution was added a solution of $\mathrm{Ni}(\mathrm{COD})_{2}(0.050 \mathrm{~g}, 0.18 \mathrm{mmol})$ in THF $(5 \mathrm{~mL})$. The resulting dark brown solution was stirred overnight at $50{ }^{\circ} \mathrm{C}$. The reaction was evaporated to dryness under vacuum, resuspended in THF (6 mL), and filtered through a pad of Celite. Dark brown solid was acquired from the vapor diffusion of pentane into the solution. Yield: $0.098 \mathrm{~g}(76 \%)$. Anal. Calcd for $\mathrm{C}_{26} \mathrm{H}_{22} \mathrm{~K}_{2} \mathrm{~N}_{2} \mathrm{NiP}_{2} \cdot(\mathrm{THF})_{2}: \mathrm{C}, 57.88 ; \mathrm{H}, 5.43 ; \mathrm{N}, 3.97$. Found: C, 58.30; H, 5.19; N, 4.14 (Note: Thoroughly dried samples of $\mathbf{3}$ were found to contain two co-crystallized or potassium-bound 
THF molecules per molecule of 3 based on ${ }^{1} \mathrm{H}$ NMR integration). ${ }^{1} \mathrm{H}$ NMR $\left(\mathrm{CD}_{3} \mathrm{CN}, 400 \mathrm{MHz}\right)$ : $\delta 7.57$ (m, Ar-H, 4H), $6.87-6.79$ (m, Ar-H, 6H), 6.67 (m, Ar-H, 2H), 6.62 (m, Ar-H, 2H), 5.89 - 5.81 (m, Ar-H, 4H), 3.06 (s, $\left.\mathrm{NCH}_{2}, 4 \mathrm{H}\right) .{ }^{13} \mathrm{C}\left\{{ }^{1} \mathrm{H}\right\} \mathrm{NMR}\left(\mathrm{CD}_{3} \mathrm{CN}, 150.9 \mathrm{MHz}\right): \delta 164.7$ (t, $J=$ $4 \mathrm{~Hz}), 156.9$ (m), 136.4 (d, $J=11 \mathrm{~Hz}), 136.2$ (t, $J=6 \mathrm{~Hz}), 131.1$ (vt, $J=10 \mathrm{~Hz}), 127.5$ (s), 127.2 (s), 121.6 (s), 107.9 (s), 107.0 (s), 53.9 (s). ${ }^{31} \mathrm{P}\left\{{ }^{1} \mathrm{H}\right\}$ NMR $\left(\mathrm{CD}_{3} \mathrm{CN}, 162.0 \mathrm{MHz}\right): \delta 15.9$ (s).

$\left\{\mathbf{L i}(\mathbf{T H F})_{2}\right\}_{2}{ }^{2 \mathrm{Ph}}[\mathbf{P N N P}] \mathbf{N i}$ (4). To a stirring solution of $\mathrm{H}_{2}{ }^{4 \mathrm{Ph}}[\mathrm{PNNP}](0.106 \mathrm{~g}, 0.183 \mathrm{mmol})$ in THF $(10 \mathrm{~mL})$ was added a $1.6 \mathrm{M}$ solution of ${ }^{n} \mathrm{BuLi}$ in hexane $(0.35 \mathrm{~mL}, 0.56 \mathrm{mmol})$ dropwise at room temperature. The resulting orange-yellow solution was stirred for $1 \mathrm{~h}$. To the stirring solution was added a solution of $\mathrm{Ni}(\mathrm{COD})_{2}(0.050 \mathrm{~g}, 0.18 \mathrm{mmol})$ in THF $(5 \mathrm{~mL})$. The resulting dark red solution was stirred overnight, evaporated to dryness under vacuum, resuspended in THF ( $2 \mathrm{~mL}$ ), and filtered through a pad of Celite. Layering the THF solution with pentane and storing at $-30{ }^{\circ} \mathrm{C}$ resulted in the formation of dark red blocks. Yield: $0.098 \mathrm{~g}(69 \%)$. Anal. Calcd for $\mathrm{C}_{26} \mathrm{H}_{22} \mathrm{Li}_{2} \mathrm{~N}_{2} \mathrm{NiP}_{2}$. (THF) $)_{4}$ : C, 64.23; H, 6.93; N, 3.57. Found: C, 64.04; H, 6.66; N, 3.45. ${ }^{1} \mathrm{H}$ NMR ( $\left.\mathrm{C}_{6} \mathrm{D}_{6}, 400 \mathrm{MHz}\right): \delta 8.24$ (br, Ar-H, 4H), 7.88 (br, Ar-H, 2H), 7.22 (vt, Ar-H, 2H), 7.06 (vt, Ar-H, 2H), 6.90 (m, Ar-H, 4H), 6.76 (vt, Ar-H, 2H), 6.69 (m, Ar-H, 2H), 3.35 (s, $\left.\mathrm{NCH}_{2}, 4 \mathrm{H}\right)$. ${ }^{13} \mathrm{C}\left\{{ }^{1} \mathrm{H}\right\}$ NMR $\left(\mathrm{C}_{6} \mathrm{D}_{6}, 150.9 \mathrm{MHz}\right): \delta 163.2(\mathrm{~s}), 151.4(\mathrm{~s}), 137.9(\mathrm{~s}), 135.1(\mathrm{~s}), 130.1(\mathrm{~s}), 128.3(\mathrm{~s})$, $127.5(\mathrm{~s}), 123.0(\mathrm{~s}), 114.5(\mathrm{~s}), 111.0(\mathrm{~s}), 54.6(\mathrm{~s}) .{ }^{31} \mathrm{P}\left\{{ }^{1} \mathrm{H}\right\} \operatorname{NMR}\left(\mathrm{C}_{6} \mathrm{D}_{6}, 162.0 \mathrm{MHz}\right): \delta-12.5(\mathrm{~s})$.

Crystallographic Studies. Single crystals were obtained from vapor diffusion of $\mathrm{CH}_{2} \mathrm{Cl}_{2} / \mathrm{Et}_{2} \mathrm{O}(\mathbf{1})$ or $\mathrm{THF} /$ pentane solutions (2 and 4) and mounted on a MiTeGen micromount using ParatoneN oil in air. The data were collected on a Bruker Nonius diffractometer with an APEX II charge coupled detector (CCD) at 100(2) or 150(2) K using an Oxford Cryostreams low temperature device. The instrument was equipped with a graphite-monochromated Mo Ka radiation source. All manipulations including data collection, integration, scaling, and absorption 
corrections were carried out using the Bruker Apex2 software. ${ }^{2}$ The structures were solved with Direct Methods (SHELXT) and non-hydrogen atoms were confirmed with least-square method (SHELXL). ${ }^{3}$ Highly-disordered solvent molecules in $\mathbf{2}$ were eliminated using a solvent mask, which left two pockets with the volume of $269.3 \AA^{3}$ and $269.3 \AA^{3}$ and with electron density of 77.9 and 78.3, respectively. The positional disorder of the carbon and/or oxygen atoms of the THF molecules in $\mathbf{2}$ and $\mathbf{4}$ was modeled by refining over two positions of each atom while setting the sum of site occupancy factor to 1 . The position of all hydrogen atoms was idealized and they were allowed to ride on the attached carbon atoms. The final refinement included anisotropic temperature factors on all non-hydrogen atoms. Structure solution and refinement were performed with Olex, ${ }^{2}$ and publication figures were generated with Mercury. 
Table S1. Crystallographic data for ${ }^{4 \mathrm{Ph}}[\mathrm{PNNP}] \mathrm{Ni}(\mathbf{1}), \quad\left\{\mathrm{K}(\mathrm{THF})_{4}\right\}^{3 \mathrm{Ph}}[\mathrm{PNNP}] \mathrm{Ni}$ (2), and $\left\{\mathrm{Li}(\mathrm{THF})_{2}\right\}_{2}{ }^{2 \mathrm{Ph}}[\mathrm{PNNP}] \mathrm{Ni}(\mathbf{4})$.

\begin{tabular}{cccc}
\hline & $\mathbf{1}$ & $\mathbf{2}$ & $\mathbf{4}$ \\
\hline formula & $\mathrm{C}_{38} \mathrm{H}_{32} \mathrm{~N}_{2} \mathrm{NiP}_{2}$ & $\mathrm{C}_{48} \mathrm{H}_{59} \mathrm{KN}_{2} \mathrm{NiO}_{4} \mathrm{P}_{2}$ & $\mathrm{C}_{42} \mathrm{H}_{54} \mathrm{Li}_{2} \mathrm{~N}_{2} \mathrm{NiO}_{4} \mathrm{P}_{2}$ \\
$\mathrm{FW}\left(\mathrm{g} \mathrm{mol}^{-1}\right)$ & 637.30 & 887.72 & 785.40 \\
crystal system & Monoclinic & Triclinic & Triclinic \\
space group & $\mathrm{C} 2 / \mathrm{c}$ & $\mathrm{P}-1$ & $\mathrm{P}-1$ \\
$\mathrm{a}(\AA)$ & $15.4121(10)$ & $11.4099(10)$ & $8.8491(6)$ \\
$\mathrm{b}(\AA)$ & $9.7889(7)$ & $14.4585(12)$ & $10.5397(7)$ \\
$\mathrm{c}(\AA)$ & $19.6930(13)$ & $17.1918(16)$ & $23.5240(16)$ \\
$\alpha(\mathrm{deg})$ & 90 & $80.758(3)$ & $99.090(2)$ \\
$\beta(\mathrm{deg})$ & $96.737(2)$ & $75.613(3)$ & $91.948(2)$ \\
$\gamma(\mathrm{deg})$ & 90 & $77.557(3)$ & $113.224(2)$ \\
volume $\left(\AA^{3}\right)$ & $2950.5(3)$ & $2665.4(4)$ & $1979.7(2)$ \\
$\mathrm{Z}$ & 4 & 2 & 2 \\
$\left.\rho_{\text {calc }}(\mathrm{g} \mathrm{cm})^{-3}\right)$ & 1.435 & 1.106 & 1.318 \\
$\left.\mu(\mathrm{mm})^{-1}\right)$ & 0.798 & 0.540 & 0.614 \\
$\mathrm{~F}(000)$ & 1328 & 940 & 832 \\
$\theta$ range $(\mathrm{deg})$ & $2.47 / 26.46$ & $1.23 / 26.44$ & $0.88 / 26.41$ \\
$\mathrm{R}(\mathrm{int})$ & 0.0452 & 0.0453 & 0.0551 \\
data/restraints/parameters & $3045 / 0 / 195$ & $10959 / 24 / 481$ & $8124 / 2 / 489$ \\
$\mathrm{GOF}$ & 1.063 & 1.069 & 1.020 \\
$\mathrm{R}_{1}[I>2 \sigma(I)]^{\mathrm{a}}$ & 0.0357 & 0.0507 & 0.0340 \\
$w R_{2}(\mathrm{all} \mathrm{data)})^{\mathrm{b}}$ & 0.0994 & 0.1525 & 0.0794 \\
Largest Peak/Hole $\left(\mathrm{e} \cdot \AA^{-3}\right)$ & $0.645 /-0.277$ & $0.874 /-0.819$ & $0.308 /-0.252$ \\
Temp $(\mathrm{K})$ & $100(2)$ & $150(2)$ & $100(2)$ \\
\hline
\end{tabular}

${ }^{\mathrm{a}} \mathrm{R}_{1}=\sum\left|F_{o}\right|-\left|F_{c}\right||/| \sum\left|F_{o}\right|$ for reflections with $F_{o}{ }^{2}>2 \sigma\left(F_{o}{ }^{2}\right)$.

${ }^{\mathrm{b}} \mathrm{wR}_{2}=\left[\sum w\left(F_{o}^{2}-F_{c}^{2}\right)^{2} / \sum\left(F_{o}^{2}\right)^{2}\right]^{1 / 2}$ for all reflections. 


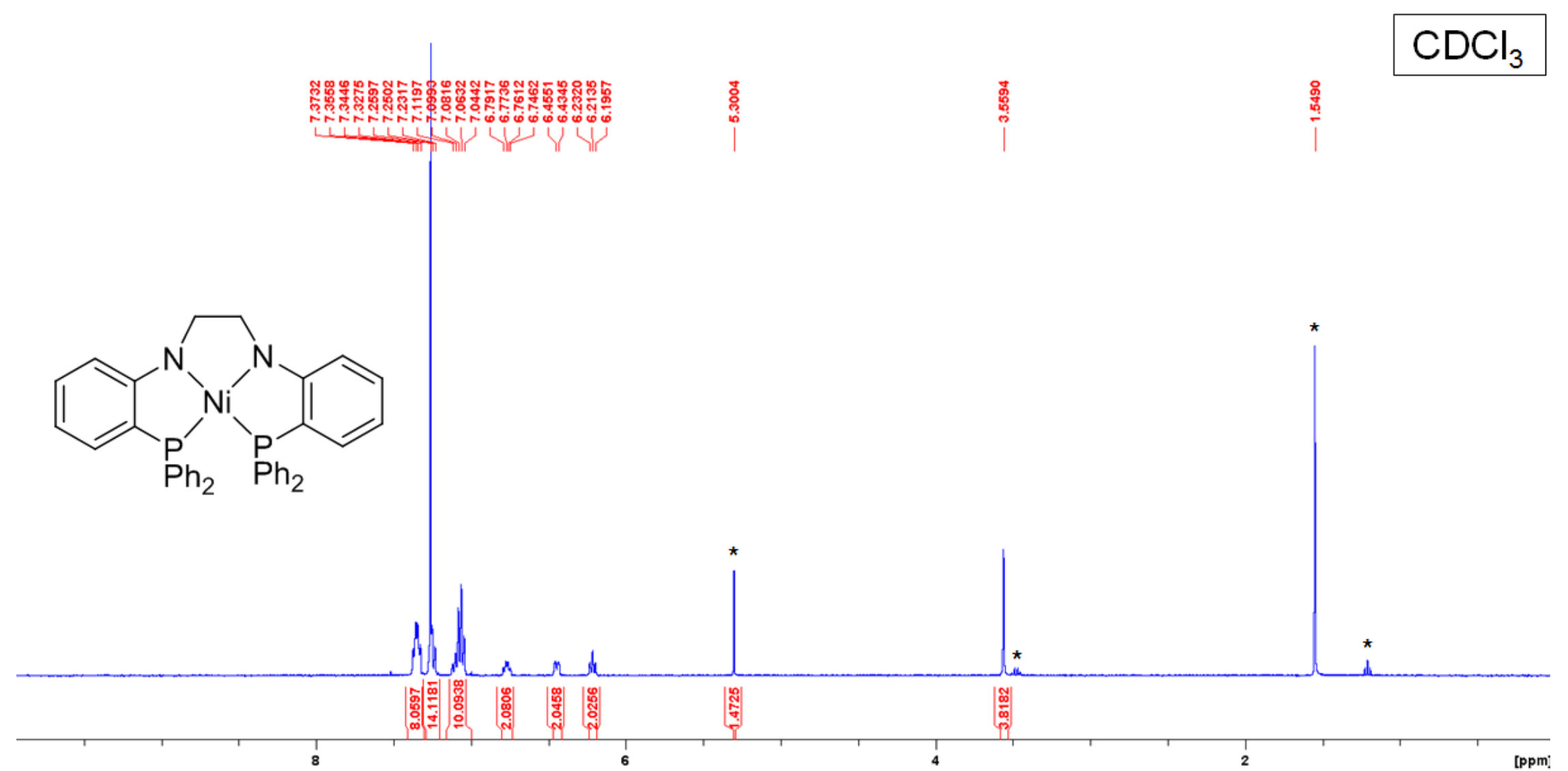

Figure S1. ${ }^{1} \mathrm{H}$ NMR spectrum for ${ }^{4 \mathrm{Ph}}[\mathrm{PNNP}] \mathrm{Ni}(\mathbf{1})$ in $\mathrm{CDCl}_{3}$. The $*$ symbol indicates resonances assigned to residual $\mathrm{CH}_{2} \mathrm{Cl}_{2}, \mathrm{Et}_{2} \mathrm{O}$, and water. 


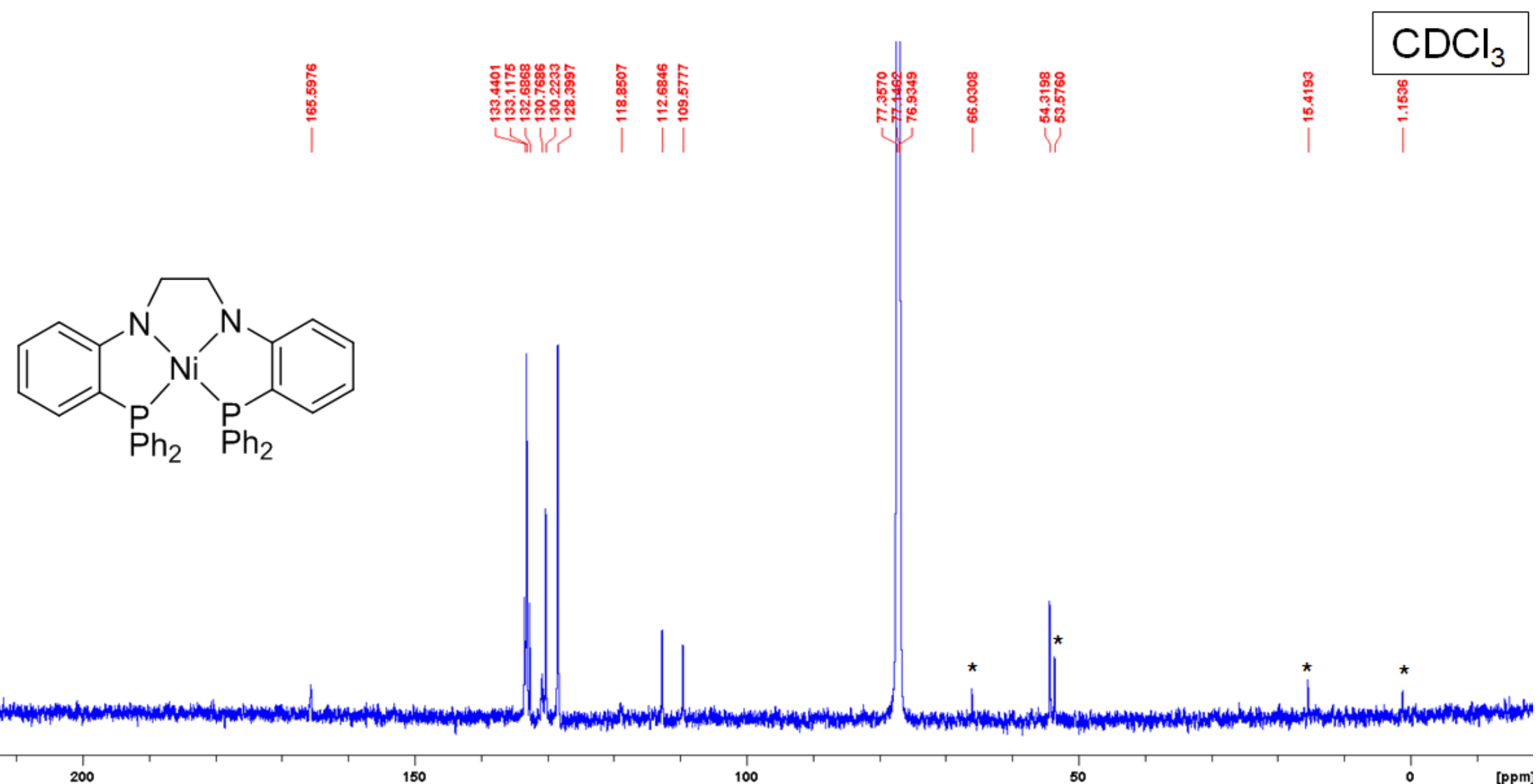

Figure S2. ${ }^{13} \mathrm{C}\left\{{ }^{1} \mathrm{H}\right\}$ NMR spectrum for ${ }^{4 P h}[\mathrm{PNNP}] \mathrm{Ni}(\mathbf{1})$ in $\mathrm{CDCl}_{3}$. The $*$ symbol indicates resonances assigned to residual $\mathrm{Et}_{2} \mathrm{O}$, $\mathrm{CH}_{2} \mathrm{Cl}_{2}$, and grease. 


\section{$\mathrm{CDCl}_{3}$}
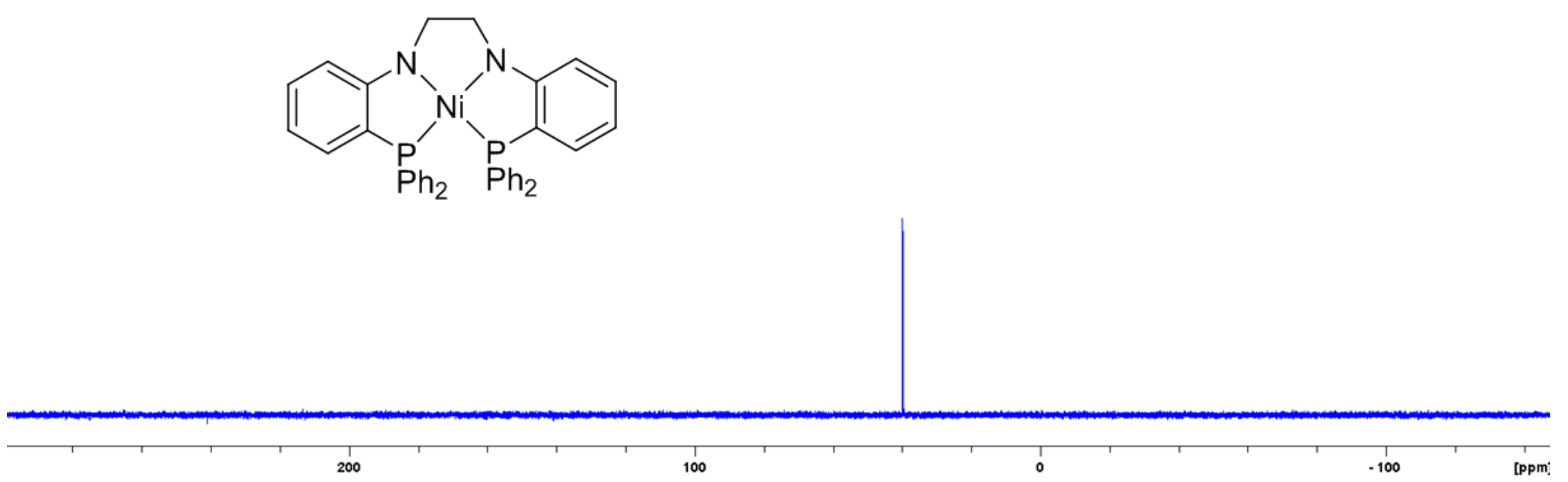

Figure S3. ${ }^{31} \mathrm{P}\left\{{ }^{1} \mathrm{H}\right\}$ NMR spectrum for ${ }^{4 \mathrm{Ph}}[\mathrm{PNNP}] \mathrm{Ni}(\mathbf{1})$ in $\mathrm{CDCl}_{3}$. 


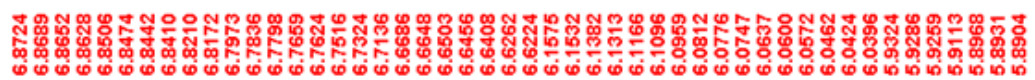

inininitil

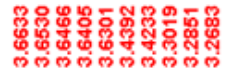

( )

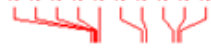

$\mathrm{CD}_{3} \mathrm{CN}$
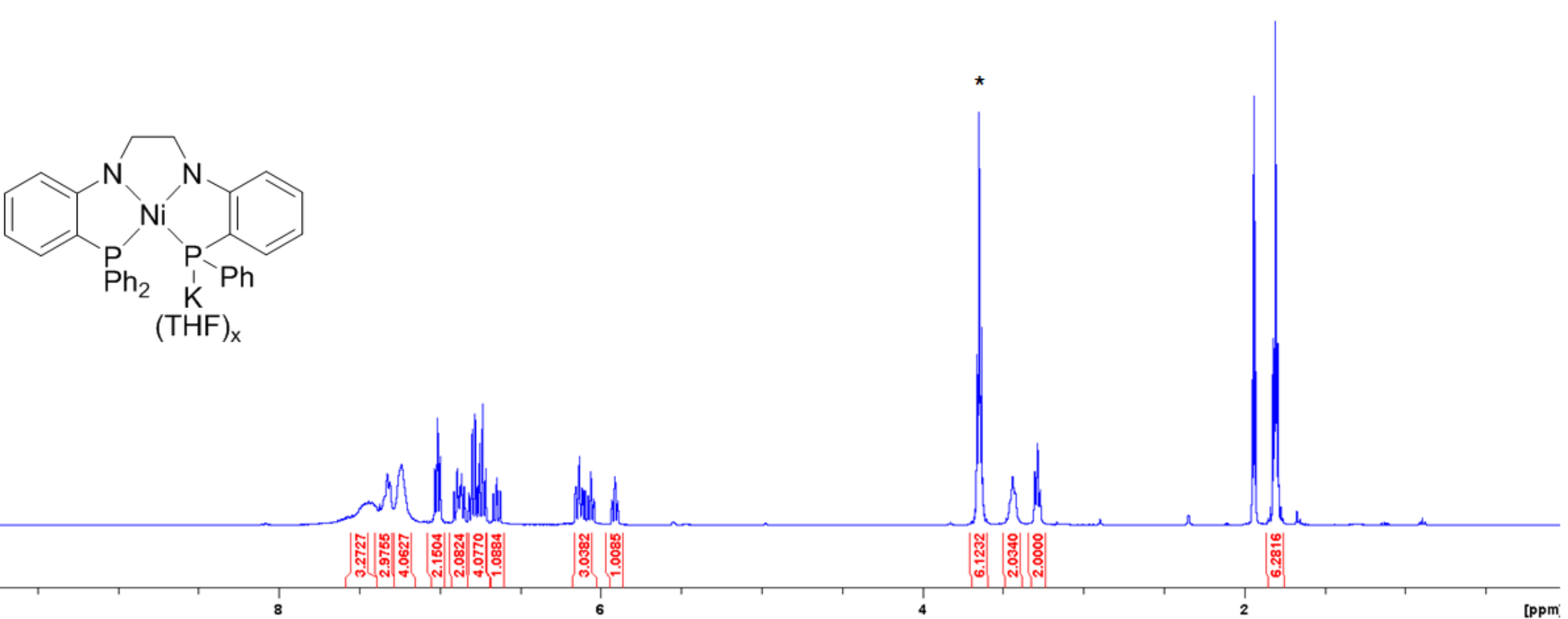

Figure S4. ${ }^{1} \mathrm{H}$ NMR spectrum for $\left\{\mathrm{K}(\mathrm{THF})_{\mathrm{x}}\right\}^{3 \mathrm{Ph}}[\mathrm{PNNP}] \mathrm{Ni}(\mathbf{2})$ in $\mathrm{CD}_{3} \mathrm{CN}$. The $*$ symbol indicates resonances assigned to THF. 


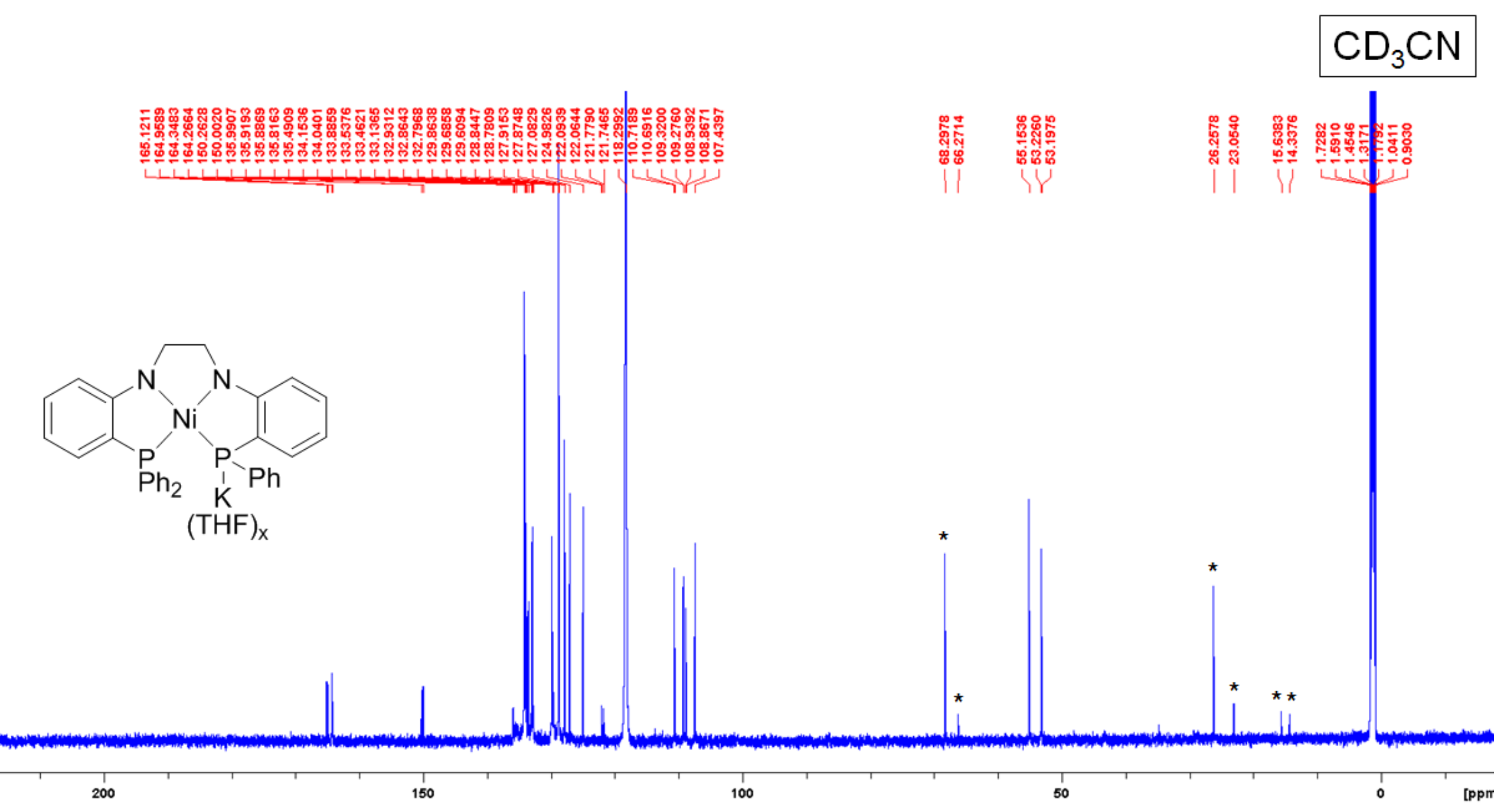

Figure S5. ${ }^{13} \mathrm{C}\left\{{ }^{1} \mathrm{H}\right\}$ NMR spectrum for $\left\{\mathrm{K}(\mathrm{THF})_{\mathrm{x}}\right\}{ }^{3 \mathrm{Ph}}[\mathrm{PNNP}] \mathrm{Ni}(\mathbf{2})$ in $\mathrm{CD}_{3} \mathrm{CN}$. The $*$ symbol indicates resonances assigned to THF, $\mathrm{Et}_{2} \mathrm{O}$, and pentane. 


\section{$\mathrm{CD}_{3} \mathrm{CN}$}

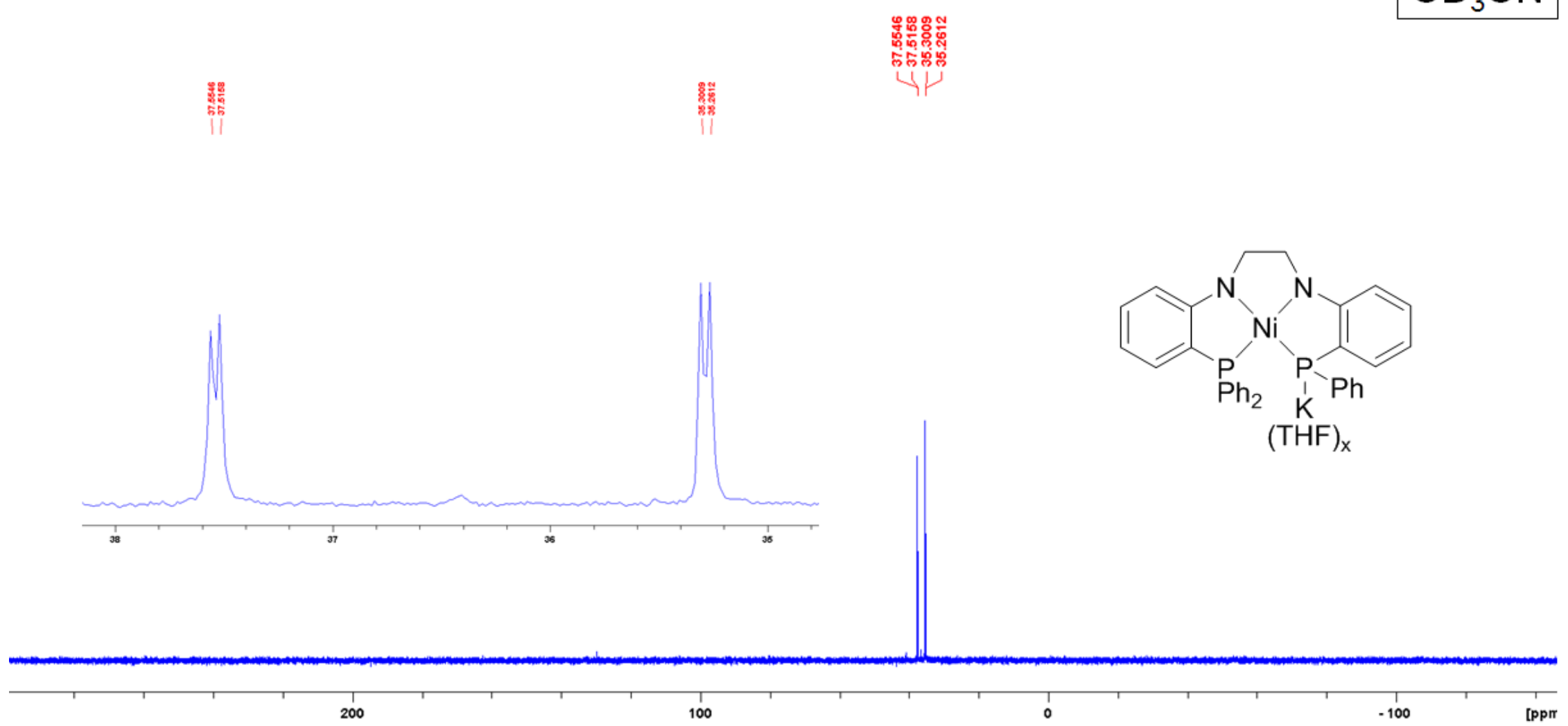

Figure S6. ${ }^{31} \mathrm{P}\left\{{ }^{1} \mathrm{H}\right\}$ NMR spectrum for $\left\{\mathrm{K}(\mathrm{THF})_{\mathrm{x}}\right\}{ }^{3 \mathrm{Ph}}[\mathrm{PNNP}] \mathrm{Ni}(\mathbf{2})$ in $\mathrm{CD}_{3} \mathrm{CN}$. 


\section{$\mathrm{CD}_{3} \mathrm{CN}$}
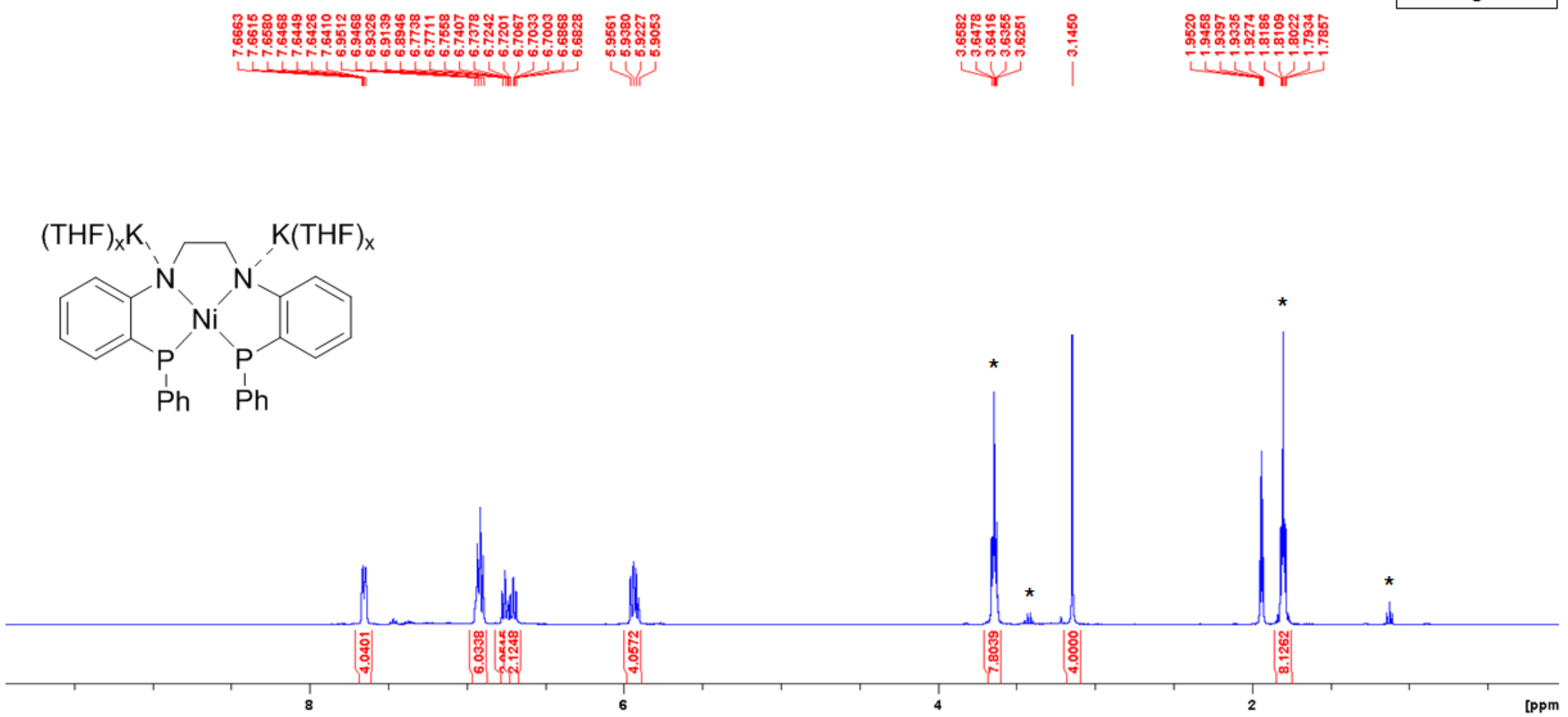

Figure S7. ${ }^{1} \mathrm{H}$ NMR spectrum for $\left\{\mathrm{K}(\mathrm{THF})_{\mathrm{x}}\right\}_{2}{ }^{2 \mathrm{Ph}}[\mathrm{PNNP}] \mathrm{Ni}(\mathbf{3})$ in $\mathrm{CD}_{3} \mathrm{CN}$. The * symbol indicates resonances assigned to THF and $\mathrm{Et}_{2} \mathrm{O}$. 


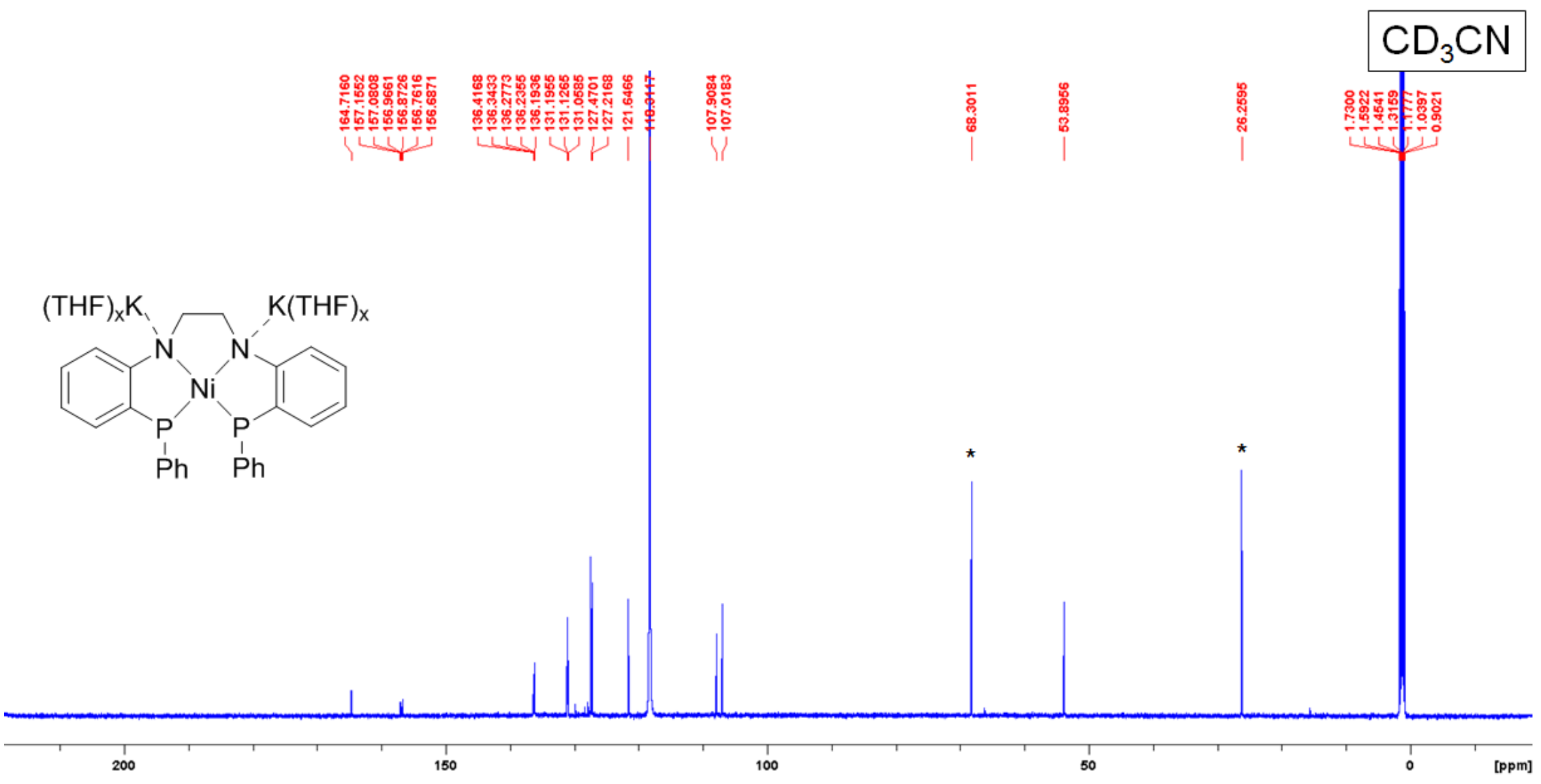

Figure S8. ${ }^{13} \mathrm{C}\left\{{ }^{1} \mathrm{H}\right\}$ NMR spectrum for $\left\{\mathrm{K}(\mathrm{THF})_{\mathrm{x}}\right\}_{2}{ }^{2 \mathrm{Ph}}[\mathrm{PNNP}] \mathrm{Ni}(\mathbf{3})$ in $\mathrm{CD}_{3} \mathrm{CN}$. The $*$ symbol indicates resonances assigned to residual THF. 


\section{$\mathrm{CD}_{3} \mathrm{CN}$}

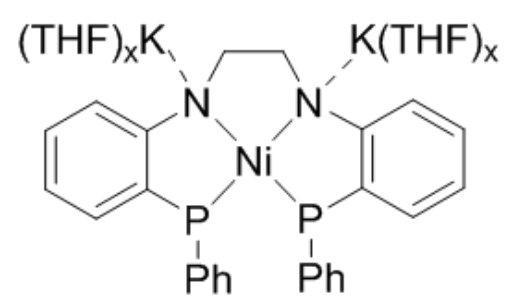

$\mathrm{Ph}$

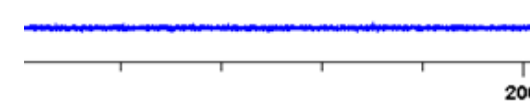

200

(2)
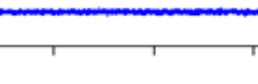

Figure S9. ${ }^{31} \mathrm{P}\left\{{ }^{1} \mathrm{H}\right\}$ NMR spectrum for $\left\{\mathrm{K}(\mathrm{THF})_{\mathrm{x}}\right\}_{2}{ }^{2 \mathrm{Ph}}[\mathrm{PNNP}] \mathrm{Ni}(3)$ in $\mathrm{CD}_{3} \mathrm{CN}$. 


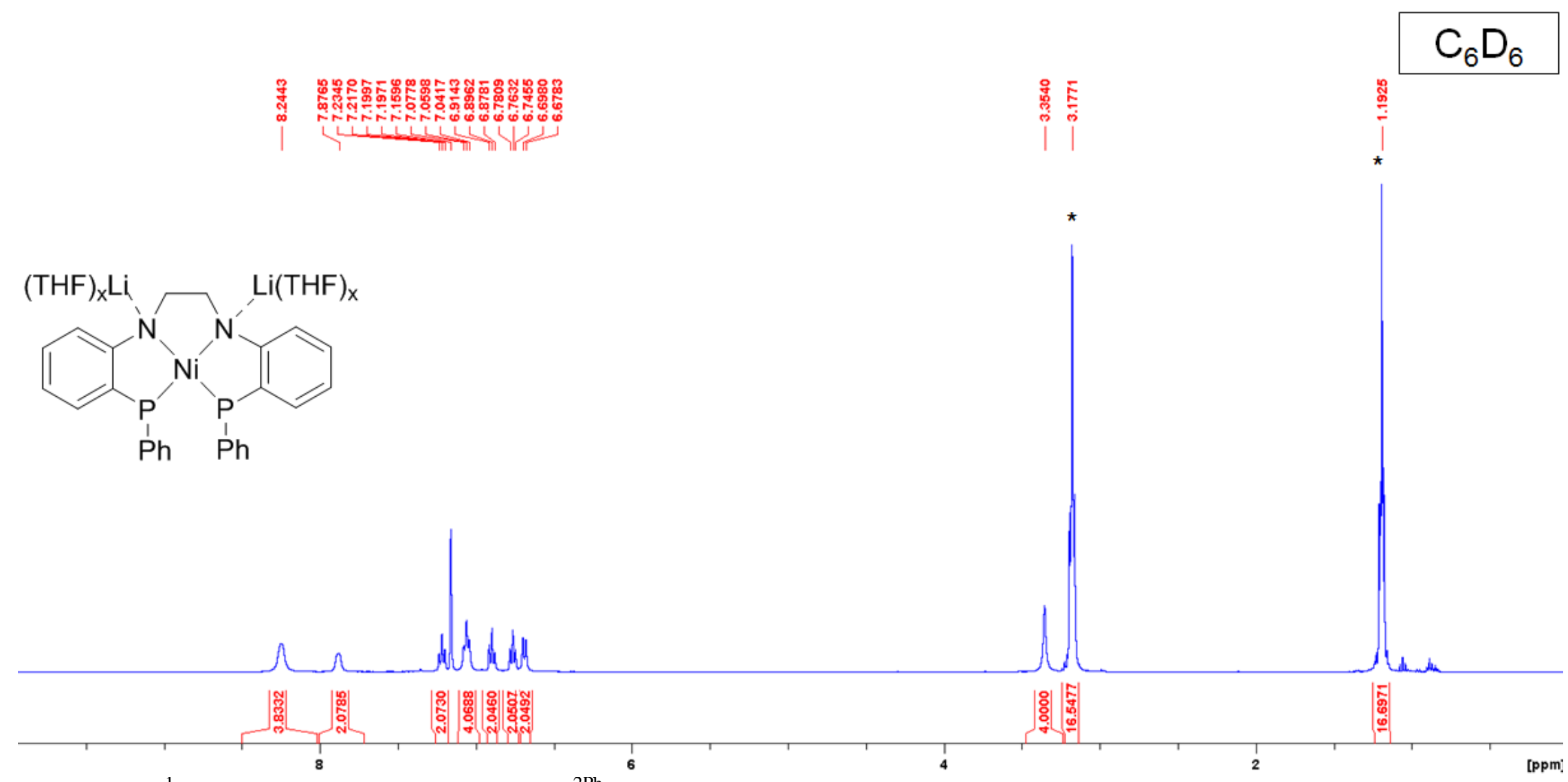

Figure S10. ${ }^{1} \mathrm{H}$ NMR spectrum for $\left\{\mathrm{Li}(\mathrm{THF})_{2}\right\}_{2}{ }^{2 \mathrm{Ph}}[\mathrm{PNNP}] \mathrm{Ni}(\mathbf{4})$ in $\mathrm{C}_{6} \mathrm{D}_{6}$. The $*$ symbol indicates resonances assigned to THF. 


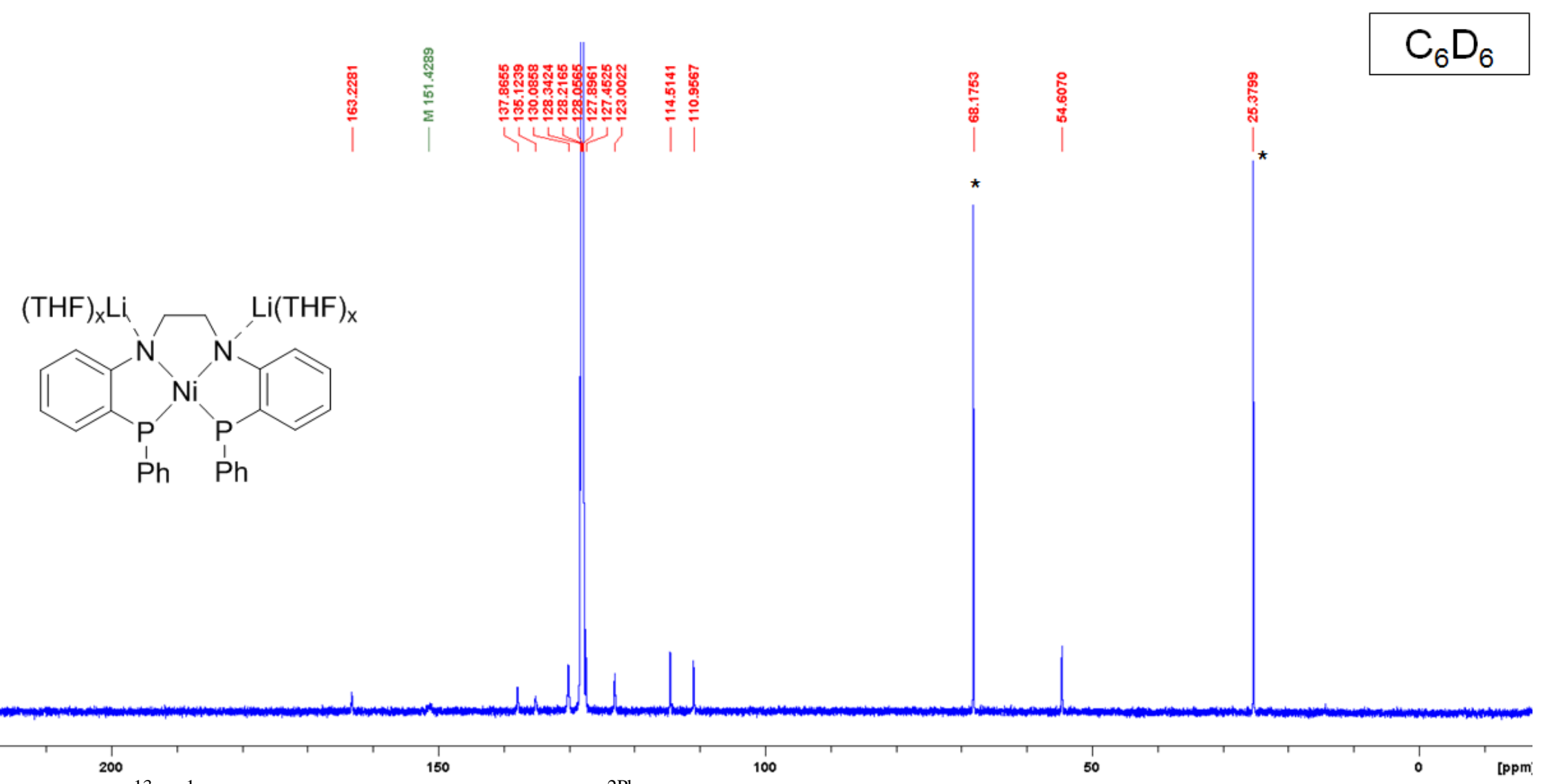

Figure S11. ${ }^{13} \mathrm{C}\left\{{ }^{1} \mathrm{H}\right\}$ NMR spectrum for $\left\{\mathrm{Li}(\mathrm{THF})_{2}\right\}_{2}{ }^{2 \mathrm{Ph}}[\mathrm{PNNP}] \mathrm{Ni}(4)$ in $\mathrm{C}_{6} \mathrm{D}_{6}$. The ${ }^{*}$ symbol indicates resonances assigned to THF. 


\section{$\mathrm{C}_{6} \mathrm{D}_{6}$}
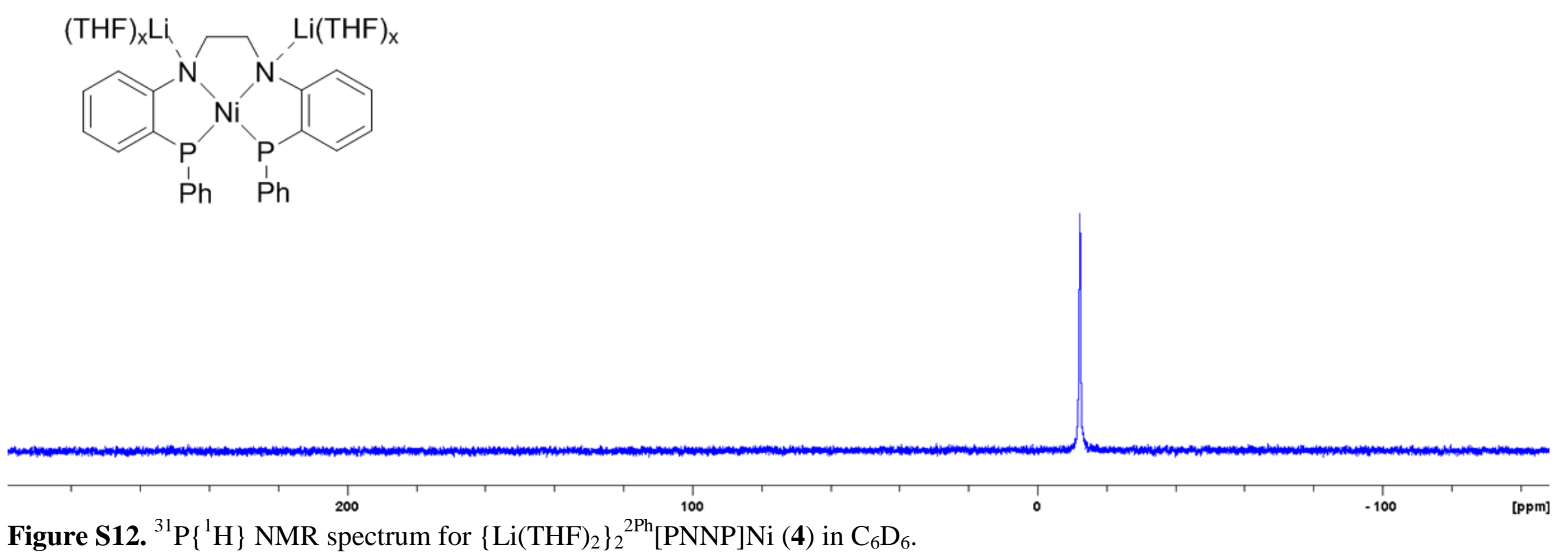

Figure S12. ${ }^{31} \mathrm{P}\left\{{ }^{1} \mathrm{H}\right\}$ NMR spectrum for $\left\{\mathrm{Li}(\mathrm{THF})_{2}\right\}_{2}{ }^{2 \mathrm{Ph}}[\mathrm{PNNP}] \mathrm{Ni}(4)$ in $\mathrm{C}_{6} \mathrm{D}_{6}$. 


\section{$\mathrm{CD}_{3} \mathrm{CN}$}
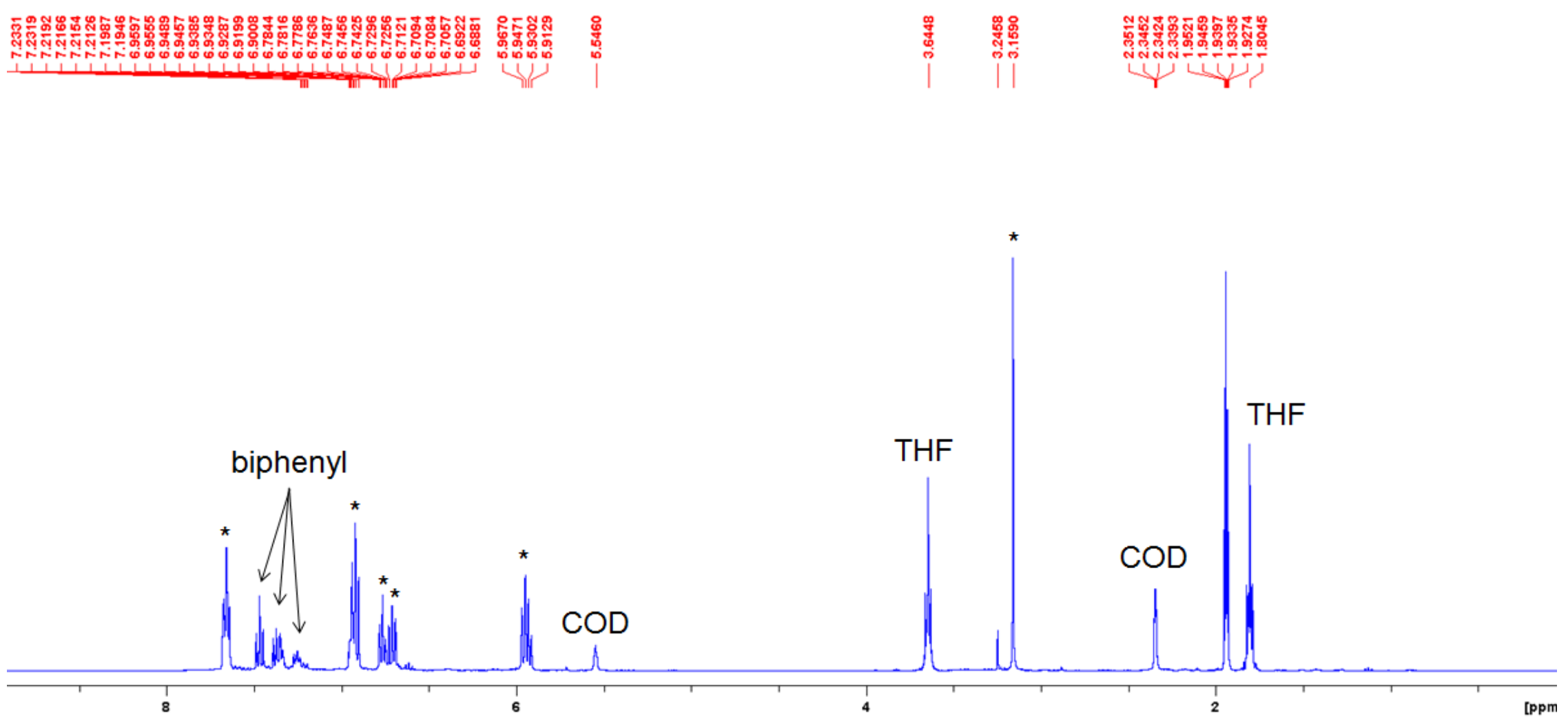

Figure S13. ${ }^{1} \mathrm{H}$ NMR spectrum of the reaction of $\mathrm{Ni}(\mathrm{COD})_{2}, \mathrm{H}_{2}{ }^{4 \mathrm{Ph}}[\mathrm{PNNP}]$, and $3 \mathrm{KH}$ carried out in THF, after volatiles were removed under vacuum. The $*$ symbol indicates resonances associated with $\mathbf{3}$. 


\section{$\mathrm{CD}_{3} \mathrm{CN}$}
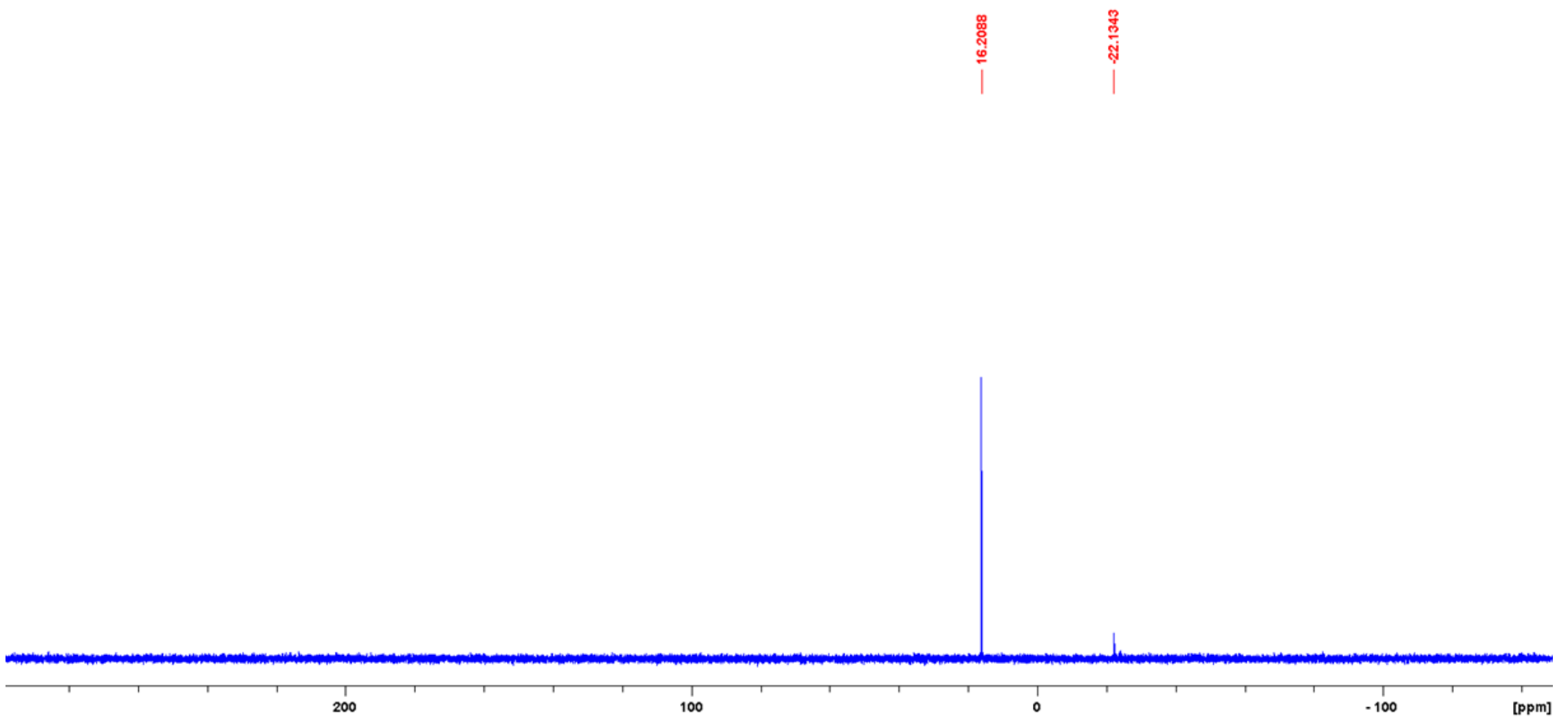

Figure S14. ${ }^{31} \mathrm{P}\left\{{ }^{1} \mathrm{H}\right\}$ NMR spectrum of the reaction of $\mathrm{Ni}(\mathrm{COD})_{2}, \mathrm{H}_{2}{ }^{4 \mathrm{Ph}}[\mathrm{PNNP}]$, and $3 \mathrm{KH}$ carried out in THF, after volatiles were removed under vacuum. 


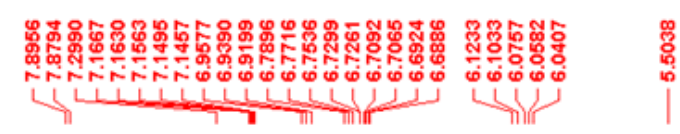

\section{benzene}

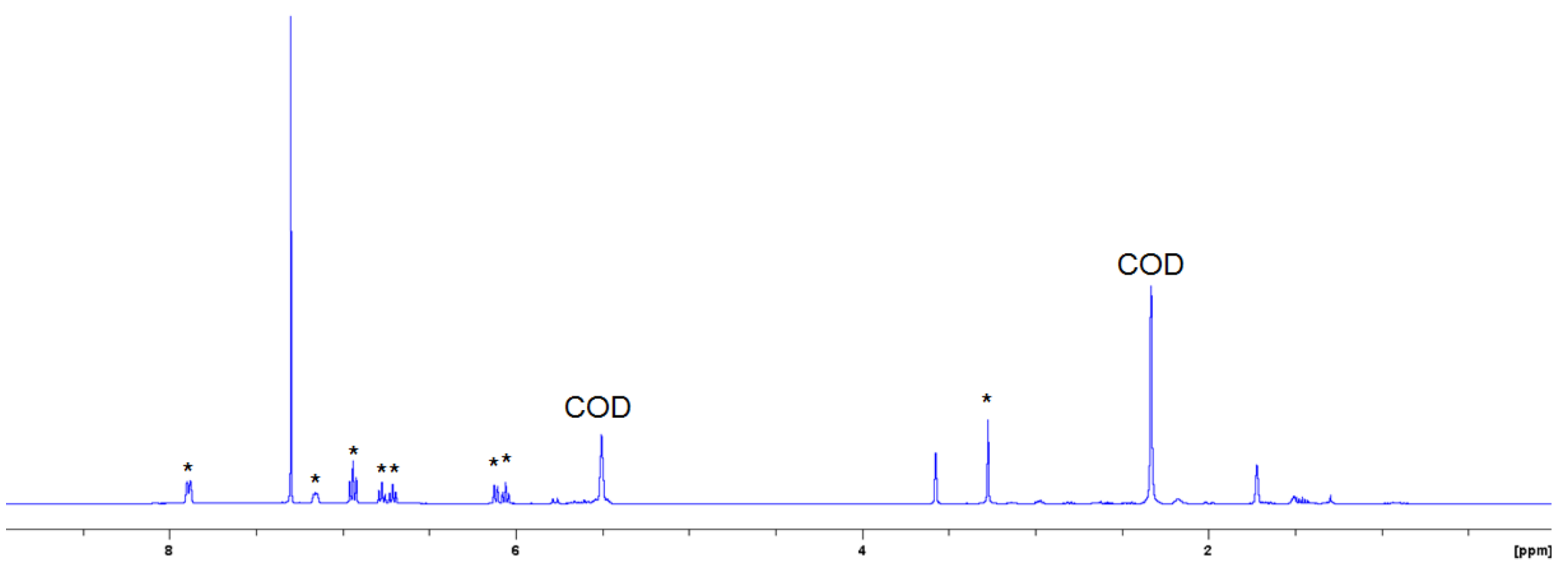

Figure S15. ${ }^{1} \mathrm{H}$ NMR spectrum of the reaction of $\mathrm{Ni}(\mathrm{COD})_{2}, \mathrm{H}_{2}{ }^{4 \mathrm{Ph}}[\mathrm{PNNP}]$, and $3 \mathrm{KH}$ carried out in THF-d 8 . The $*$ symbol indicates resonances associated with $\mathbf{3}$. 


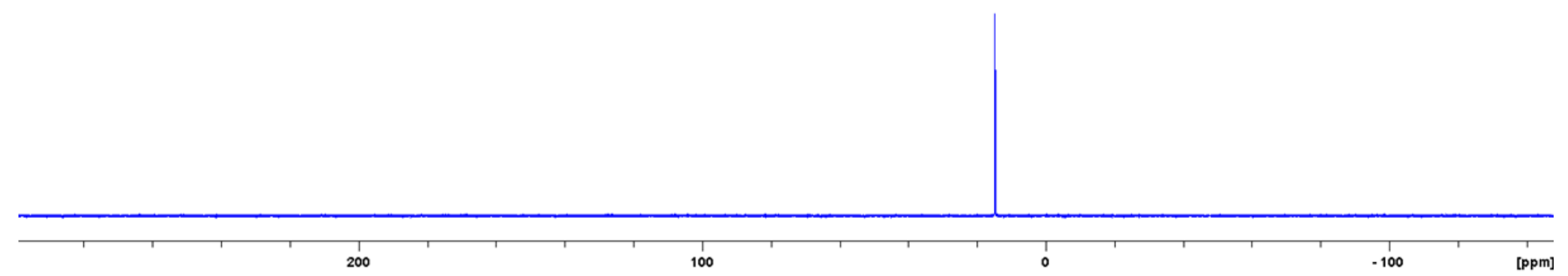

Figure S16. ${ }^{31} \mathrm{P}\left\{{ }^{1} \mathrm{H}\right\}$ NMR spectrum for the reaction of $\mathrm{Ni}(\mathrm{COD})_{2}, \mathrm{H}_{2}{ }^{4 \mathrm{Ph}}[\mathrm{PNNP}]$, and $3 \mathrm{KH}$ carried out in THF-d . 


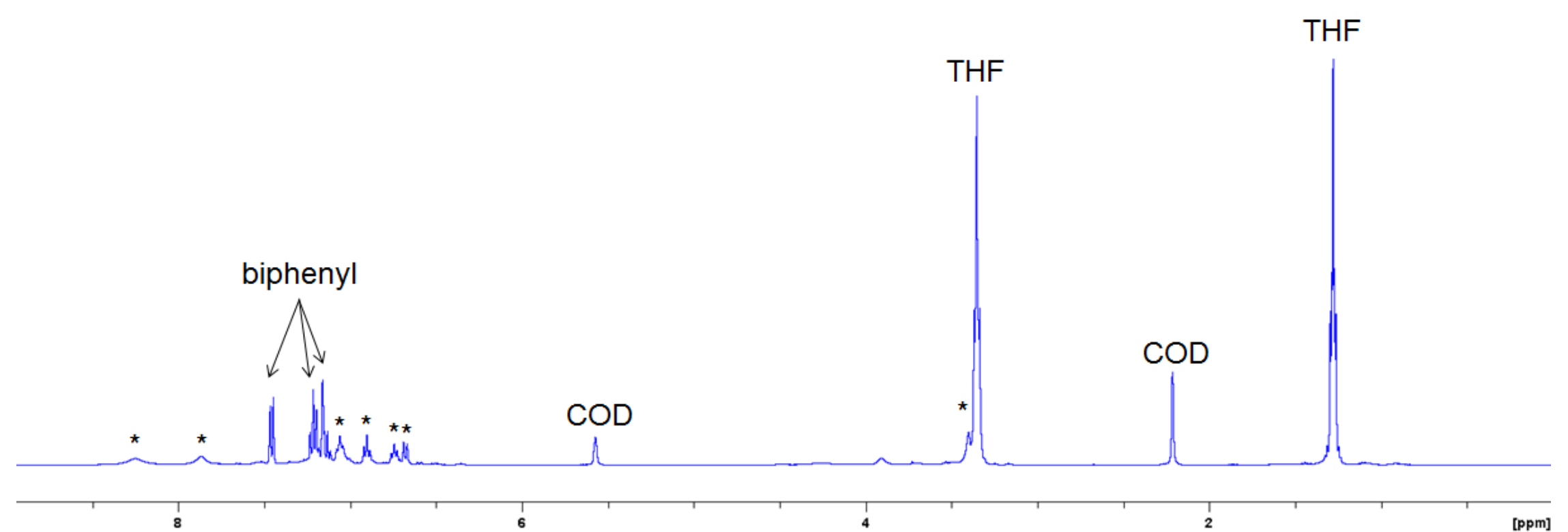

Figure S17. ${ }^{1} \mathrm{H}$ NMR spectrum of the reaction of $\mathrm{Ni}(\mathrm{COD})_{2}, \mathrm{H}_{2}{ }^{4 \mathrm{Ph}}[\mathrm{PNNP}]$, and $3{ }^{n} \mathrm{BuLi}$ carried out in THF, evaporated to dryness under vacuum, and resuspended in $\mathrm{C}_{6} \mathrm{D}_{6}$. The * symbol indicates resonances associated with 4. 

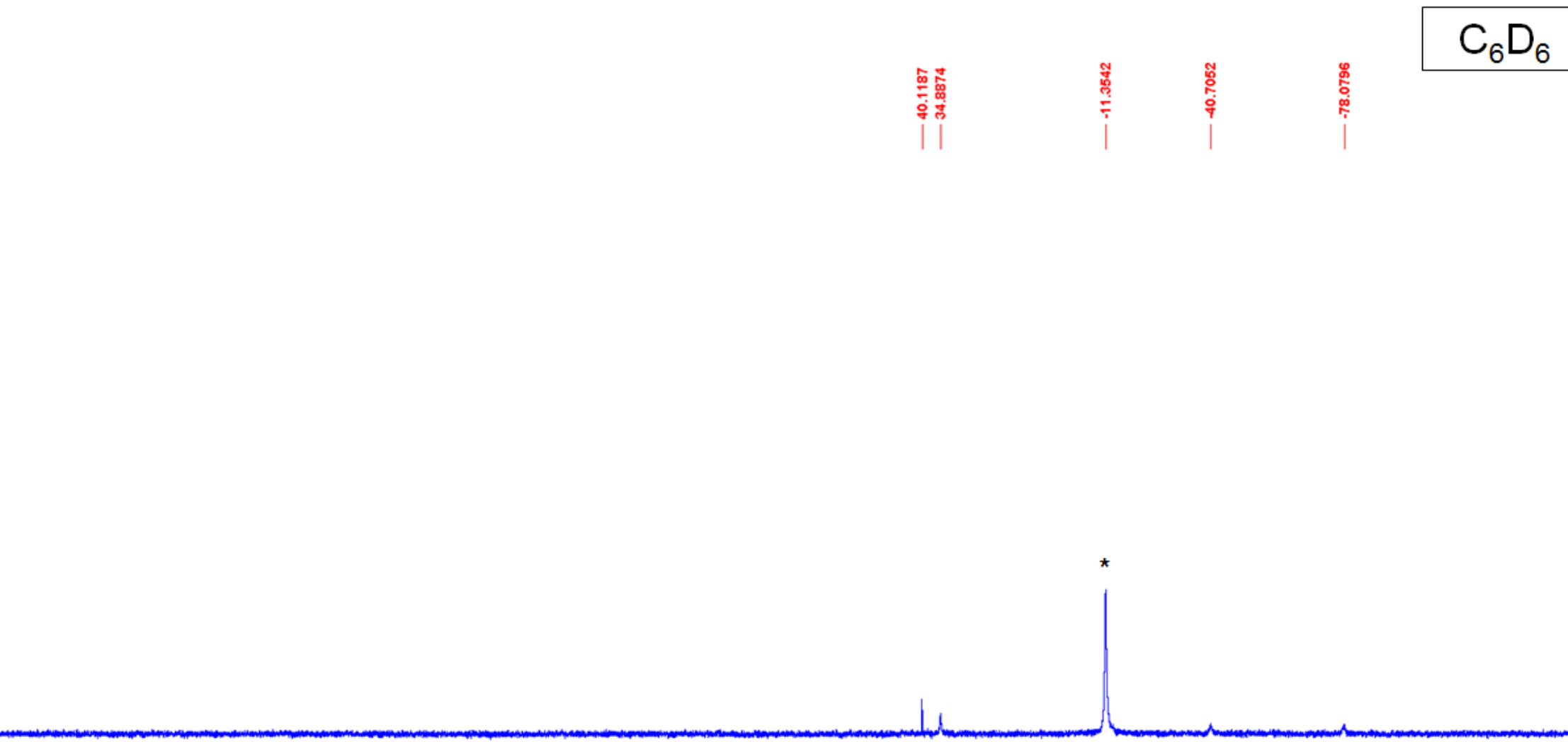

Figure S18. ${ }^{31} \mathrm{P}\left\{{ }^{1} \mathrm{H}\right\}$ NMR spectrum for the reaction of $\mathrm{Ni}(\mathrm{COD})_{2}, \mathrm{H}_{2}{ }^{4 \mathrm{Ph}}[\mathrm{PNNP}]$, and $3{ }^{n} \mathrm{BuLi}$ carried out in THF, evaporated to dryness under vacuum, and resuspended in $\mathrm{C}_{6} \mathrm{D}_{6}$. The * symbol indicates resonance associated with 4. 


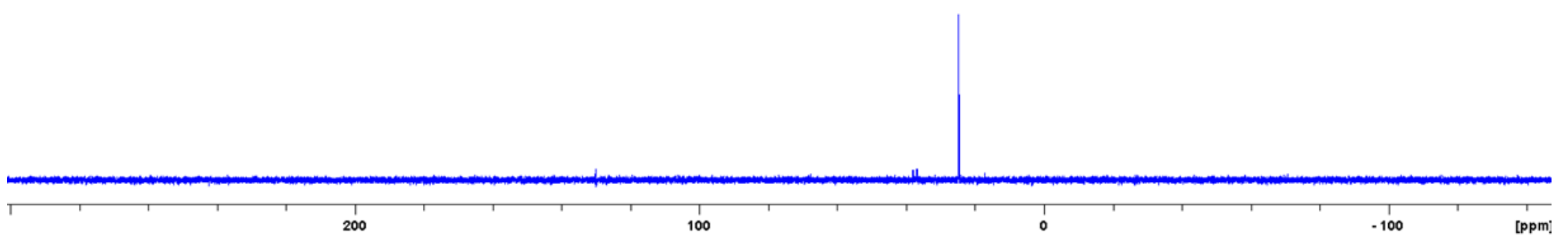

Figure S19. ${ }^{31} \mathrm{P}\left\{{ }^{1} \mathrm{H}\right\}$ NMR spectrum for the reaction of $\left\{\mathrm{K}(\mathrm{THF})_{\mathrm{x}}\right\}_{2}{ }^{2 \mathrm{Ph}}[\mathrm{PNNP}] \mathrm{Ni}(3)$ and 2 equiv 18-crown-6 in THF. 


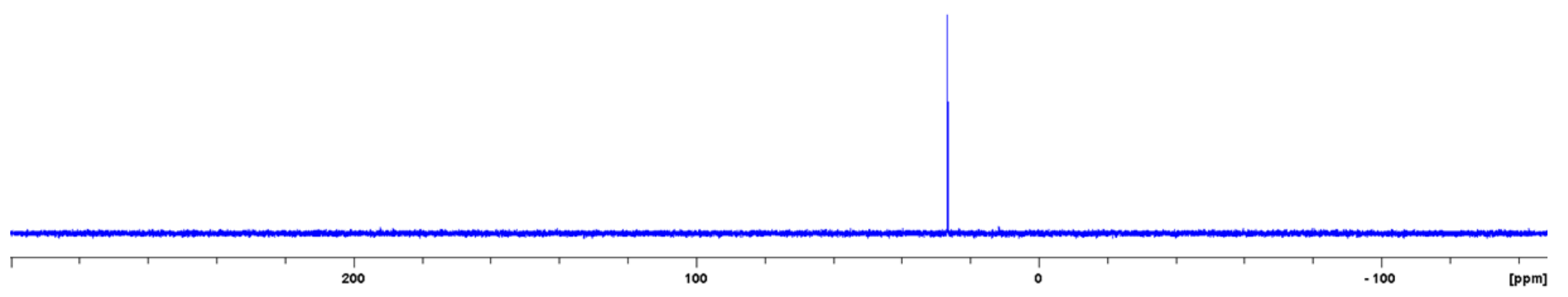

Figure S20. ${ }^{31} \mathrm{P}\left\{{ }^{1} \mathrm{H}\right\}$ NMR spectrum for the reaction of $\left\{\mathrm{Li}(\mathrm{THF})_{2}\right\}_{2}{ }^{2 \mathrm{Ph}}[\mathrm{PNNP}] \mathrm{Ni}(4)$ and 4 equiv 12-crown-4 in THF. 

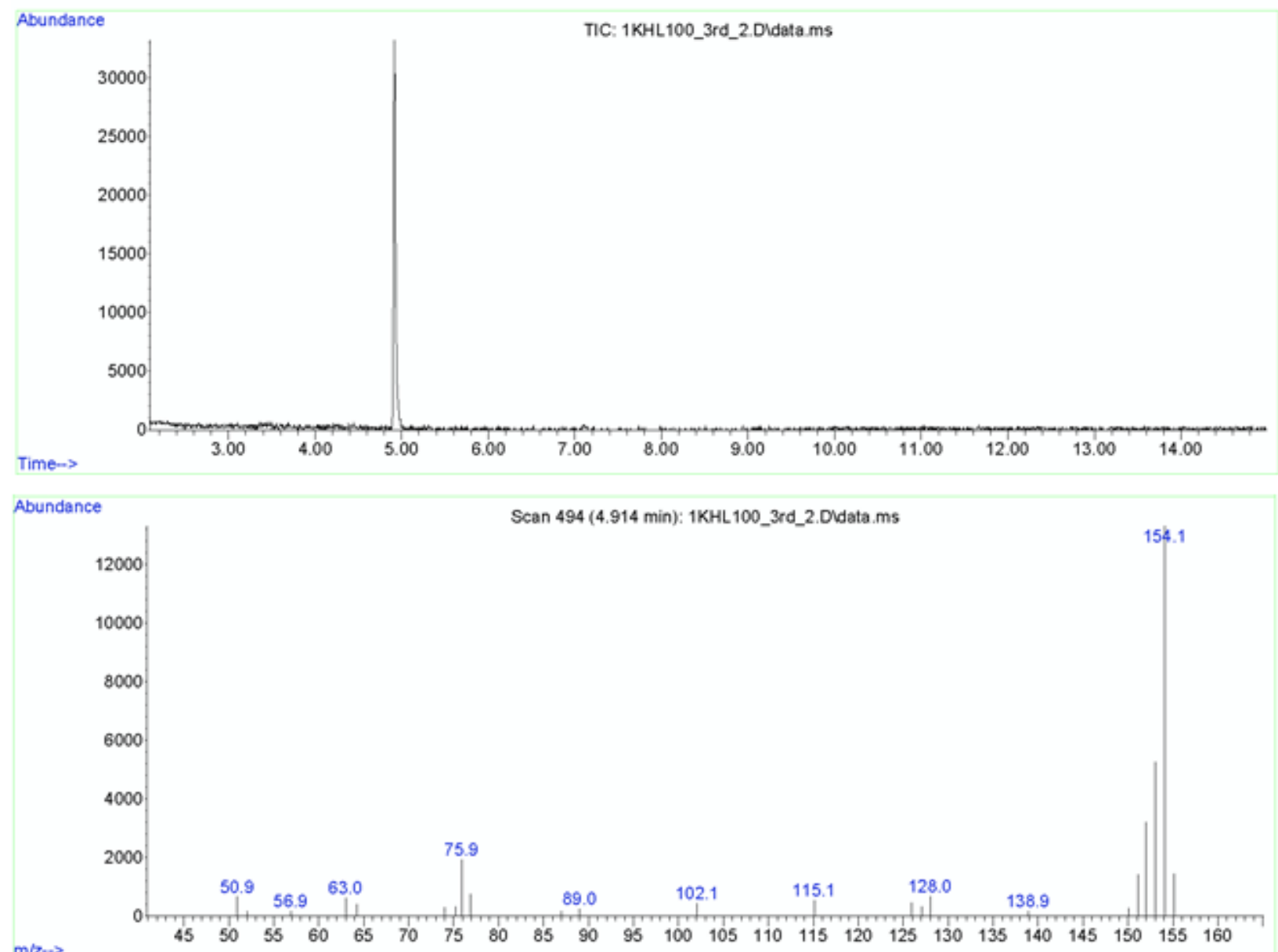

Figure S21. GC-MS chromatogram and mass spectrum for the reaction of $\mathrm{Ni}(\mathrm{COD})_{2}$, $\mathrm{H}_{2}{ }^{4 \mathrm{Ph}}[\mathrm{PNNP}]$, and $3 \mathrm{KH}$ carried out in THF, evaporated to dryness under vacuum, and resuspended in hexane. 

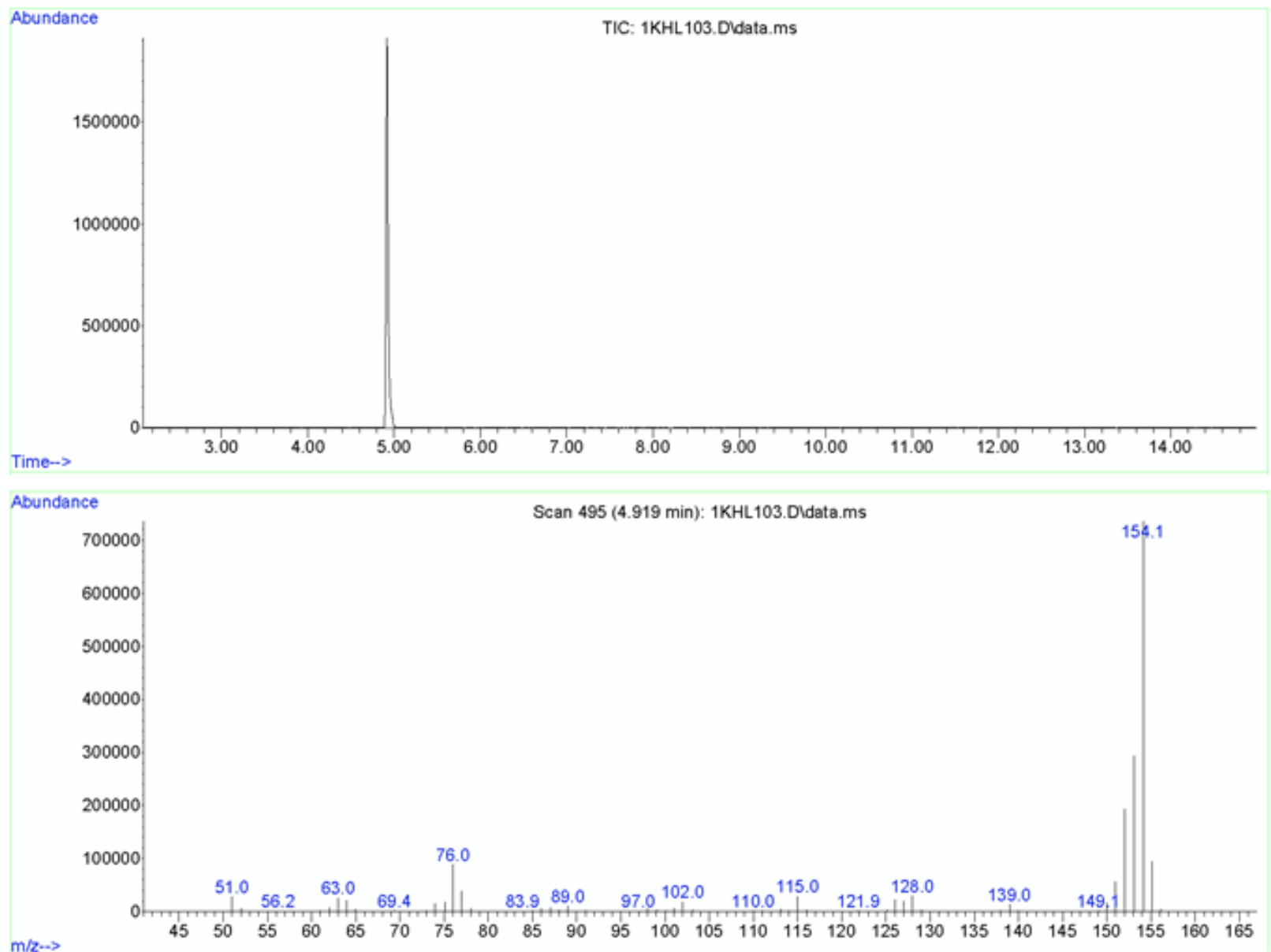

Figure S22. GC-MS chromatogram and mass spectrum for the reaction of $\mathrm{Ni}(\mathrm{COD})_{2}$, $\mathrm{H}_{2}{ }^{4 \mathrm{Ph}}[\mathrm{PNNP}]$, and $3{ }^{n} \mathrm{BuLi}$ carried out in THF, evaporated to dryness under vacuum, and resuspended in hexane. 


\section{References}

1. Day, G. S.; Pan, B.; Kellenberger, D. L.; Foxman, B. M.; Thomas, C. M. Guilty as Charged: Non-Innocent Behavior by a Pincer Ligand Featuring a Central Cationic Phosphenium Donor. Chem. Commun. 2011, 47, 3634-3636.

2. Apex 2, Version 2 User Manual, M86-E01078. Bruker Analytical X-ray Systems: Madison, WI, 2006.

3. Sheldrick, G. M. SHELXT - Integrated Space-Group and Crystal-Structure Determination. Acta Cryst. 2015, A71, 3-8. 